\title{
Modelling the earliest north-western dispersal of Mediterranean Impressed Wares: new dates and Bayesian chronological model
}

\author{
Didier Binder ${ }^{1 *}$, Philippe Lanos ${ }^{2}$, Lucia Angeli3, Louise Gomart ${ }^{1}$, Jean Guilaine4, \\ Claire Manen 5, Roberto Maggi 6, Italo M. Muntoni 7, Chiara Panelli 1,8, Giovanna Radi3, \\ Carlo Tozzi 3, Daniele Arobba 9, Janet Battentier 1, Mario Brandaglia ${ }^{10}$, Laurent Bouby ${ }^{11}$, \\ François Briois 5 , Alain Carré 1 , Claire Delhon ${ }^{1}$, Lionel Gourichon ${ }^{1}$, Philippe Marinval ${ }^{13}$, \\ Renato Nisbet ${ }^{12}$, Stefano Rossi ${ }^{14}$, Peter Rowley-Conwy ${ }^{15}$ and Stéphanie Thiébault ${ }^{16}$ \\ 1 Université Côte d'Azur, CNRS, Cultures et environnements. Préhistoire, Antiquité, Moyen Âge, Nice, FR \\ didier.binder@cepam.cnrs.fr *Corresponding author; louise.gomart@cepam.cnrs.fr; \\ chiara.panelli@gmail.com; janet.battentier@cepam.cnrs.fr; alain.carre@cepam.cnrs.fr; \\ claire.delhon@cepam.cnrs.fr; lionel.gourichon@cepam.cnrs.fr
}

2 Université Bordeaux Montaigne, CNRS, Institut de Recherche sur les Archéomatériaux, Bordeaux and Université Rennes 1, CNRS, Geosciences-Rennes, Rennes, FR philippe.lanos@univ-rennesı.fr

3 Università degli Studi di Pisa, Dipartimento di Civiltà e Forme del Sapere, Pisa, IT luciaangeli78@yahoo.it; giovanna.radi@unipi.it; tozzi@arch.unipi.it

4 Collège de France, Paris, FR jguilaine@wanadoo.fr

5 Université Toulouse, CNRS, EHESS, MCC, Travaux de Recherches Archéologiques sur les Cultures, les Espaces et les Sociétés, Toulouse, FR

claire.manen@univ-tlse2.fr; francois.briois@ehess.fr

6 Istituto Internazionale di Studi Liguri, Chiavari, IT romaggi2003@libero.it

7 Soprintendenza Archeologia, Belle Arti e Paesaggio per le Province di Barletta-Andria-Trani et Foggia, Foggia, IT italomaria.muntoni@beniculturali.it

8 Università degli studi di Genova, Dipartimento di Antichità, Filosofia e Storia, Genova, IT chiara.panelli@gmail.com

9 Museo Archeologico del Finale, Finale Ligure, IT arobba@museoarcheofinale.it

10 Università degli studi di Firenze, Studi per l'Ecologia del Quaternario, Firenze, IT mariobrandaglia@hotmail.com

11 Université Montpellier, CNRS, IRD, EPHE, Institut des Sciences de l'Evolution de Montpellier, Montpellier, FR laurent.bouby@umontpellier.fr

12 Università Ca' Foscari, Dipartimento di Studi sull'Asia e sull'Africa Mediterranea, Venezia, IT renisbet@tin.it

13 Université Montpellier, CNRS, MCC, Archéologie des Sociétés Méditerranéennes, Lattes, FR philippe.marinval@cnrs.fr

14 Soprintendenza Archeologia, Belle Arti e Paesaggio per la città metropolitana di Genova e le province di Imperia, La Spezia e Savona, Genova, IT stefano.rossi@beniculturali.it 15 Durham University, Durham, UK p.a.rowley-conwy@durham.ac.uk

16 Muséum National d'Histoire Naturelle, CNRS, Archéozoologie, Archéobotanique: Sociétés, Pratiques et Environnements, Paris, FR stephanie.thiebault@mnhn.fr 
ABSTRACT - The authors attempt to specify the diffusion pattern of the Impressed-Ware Neolithic (Impresso-cardial complex, ICC), from south-eastern Italy onto the French Mediterranean coasts. Using ChronoModel $\AA_{\text {s }}$ software, a Bayesian model was built with sets of dates obtained on well-contextualised, short-lived samples. The results highlight a clear tightening of the chronology in the so-called nuclear area (Apulia, Basilicata, Calabria) and a pioneer dispersal at record speed in the Tyrrhenian Basin. Moreover, they question the origins and initial developments of the Impressed-Wares techno-complex.

KEY WORDS - Italy; France; Neolithic; Impressed wares; Bayesian modelling

\title{
Modeliranje najzgodnejše severno-zahodne širitve posod tipa Impresso v Sredozemlju: novi datumi in Bayesov kronološki model
}

\begin{abstract}
IZVLEČEK - Avtorji poskušajo definirati vzorec difuzije neolitskih posod tipa Impresso (kompleks Impresso-cardium, ang. $k r$. ICC) iz jugovzhodne Italije do sredozemske obale Francije. Bayesovo modeliranje je bilo postavljeno s pomočjo programske opreme ChronoModel $₫$ na podlagi serije datumov kratkoživih vzorcev iz dobro definiranih kontekstov. Rezultati kažejo jasno oženje kronologije na t. i. jedrnih območjih (Apulija, Bazilikata, Kalabrija) in pionirsko širitev z rekordno hitrostjo $v$ Tirenskem morju. Avtorji prav tako opozorijo na težave pri interpretaciji začetkov in prvotnega razvoja tehno-kompleksa posod tipa Impresso.
\end{abstract}

KLJUČNE BESEDE - Italija; Francija; neolitik; posode tipa Impresso; Bayesovo modeliranje

\section{Issues}

\section{The western dispersal}

Western Mediterranean Neolithisation processes are thought to have been supported by a polythetic complex defined as Impressed Wares or the Impresso-cardial complex (ICC). Its precise sources are still controversial, despite genetic evidence concerning animals, cereals as well as humans that now clearly inscribe it in the framework of a peopling movement, originating from the Eastern Mediterranean (Hofmanová 2016). Indeed, in terms of intensity, rhythms, routes and recombination, the scenario of this dispersal is still poorly known (Binder, Guilaine 1999; Manen 2014). ICC provides huge internal diversity within, for instance, pottery styles, which makes the visibility of interaction and evolution processes rather fuzzy (Guilaine 2003). Moreover, towards the West, the Eastern-Mediterranean Neolithic package lost many of its attributes, especially in the symbolic range, and the farther West we go, the greater is this loss (Binder et al. 2014). This addresses the problem of a cultural or social drift and admixture that could be at the origin of such a declension of the Neolithic paradigm in the Western Mediterranean.

What could be at the origin of such apparent variability? On the one hand, as shown by its typical coastal impact, the north-western Mediterranean colonisation by Neolithic people was certainly based on maritime seafaring (Bernabò Brea 1950) or voyaging (Ammerman 2013), which is evidenced by the diffusion of the whole set of western Mediterranean obsidian sources, a diffusion that did not exist at all in the same area before the farmers' dispersal (Ammerman, Polgase 1997; Binder et al. 2012; Muntoni 2012; Pessina, Radi 2006; Tykot et al. 2013), and whose speed has been several times discussed (Isern et al. 2017; Zilhão 2001). In addition, such movements could have been more or less erratic, and even from diverse origins. On the other hand, the evidence of the Late Mesolithic setting in a large part of the Franco-Italian area during the 7 th millennium as well as a few Mesolithic radiocarbon dates from the first half of the $6^{\text {th }}$ millennium (e.g., in the Middle Rhône valley and in the ToscoEmilian Apennine) could support the coexistence of groups of early farmers and late hunter-gatherers, which could be at the origin of several scenarios of admixture, with consequences in terms of cultural mosaic and biological diversity (Binder 2013; Binder et al. 2017; Franco 2011; Perrin, Binder 2014; Marchand, Perrin 2017).

\section{Building reliable datasets and chronicles}

Comprehensive data are required to make this story clearer, including reliable radiocarbon chronicles from clear contexts, which is the topic of this paper. 
Building reliable and accurate chronicles depends on the rules governing proof, the capacity to run a quality approach, which means outlining some basic and generally well-known premises for dating, i.e. to use only short-lived samples (abridged SLS) and to guarantee their association with well-defined events.

The earliest ICC settlements dated within such conditions are localised in Corfu ( $\mathrm{n}=1)$, in southern $(\mathrm{n}=8)$ and central Italy $(\mathrm{n}=3)$, in the Tuscan archipelago $(\mathrm{n}=1)$, in Liguria and eastern Provence ( $\mathrm{n}$ $=4)$, and Mediterranean Languedoc $(\mathrm{n}=2)$. As a comparison, Dalmatia also provided nine ICC sites with reliable SLS-dates (Forenbaher et al. 2013; McClure et al. 2014; Produg et al. 2014).

The south-eastern and central Italian settlements considered here are significant because of the stylistic variations of Impressa pottery, following Santo Tiné's periodisation (Cipolloni Sampò et al. 1999; Grifoni Cremonesi, Radi 1999; Tiné 1987): archa$i c$, with rather disorganised impressed decoration; evolved or Guadone, with structured impressed decoration; recent, with 'graffita dentellata' and painted Lagano-da-Piede wares; a final phase, with Matera engraved and Masseria La Quercia painted styles.

For this study, we did not take into consideration the late dispersal towards the North along the Adriatic coast, and we omitted late SLS-dates from Molise (Monte Maulo) and Abruzzo (Fonti Rossi) (Skeates 1994). Likewise, among the southern Italian set of sites, late dates from Masseria Santa-Tecchia and Masseria Candelaro which pertain to the development of Red Painted Figulina Wares, mainly in the second half of the $6^{\text {th }}$ millennium BCE (Skeates 1994), are not to be taken into account in our topic, which focuses on the Impressa aspects predating the mid-6th millennium BCE.

In Provence and Mediterranean Languedoc, ICC settlements display diverse pottery styles, marked by the importance of stab-and-drag, instrumental and pinched decoration, compared to the occurrence of shell impression, especially Cardium, which is very variable depending on the sites (approx. 50\% at Pont de Roque-Haute as opposed to almost zero at Pendimoun). These Impressa aspects definitely predate the Franco-Iberian Cardial, a phase which develops during the second half of the $6^{\text {th }}$ millennium, and even mainly the last third of it (Binder et al. 2017).
Data from the major western Mediterranean islands is lacking. A significant number of Pre-Stentinello and Early Stentinello settlements, including Kronio style, is attested in Sicily, but with no SLS-dates published. No evidence of Impressa pottery sets is as yet provided in Sardinia, despite very early evidence of obsidian trade, such as at Peiro Signado (Briois et al. 2009) and Arene Candide (Ammerman, Polgase 1997). Only one early date made on charcoal is known from Su Carroppu (Lugliè 2014), with uncertainties concerning the cultural attribution of the few sherds discovered. On the basis of pottery typology, a few Impressa indices, probably predating the Tyrrhenian Cardial, are now known in Corsica at Campu Stefanu (Cesari et al. 2014) and at the Albertini rock-shelter (Binder, Nonza-Micaelli 2016 and forthcoming) but not dated yet.

Data are critically lacking in Tuscany, Lazio and Campania. It has been thought that Late Mesolithic groups in the Tosco-Emilian and Ligurian Apennine were still settled during a part of the ICC dispersal and its early development; this is based on a few radiocarbon dates obtained from Castelnovian deposits, e.g., at Lama Lite 2, US6, c. 5770-5640 cal BCE (6620 480 BP, Rome-394, charcoal) (Castelletti et al. 1994; Dini, Fioravanti 2011) and Monte Frignone 2, US2, c. 5630-5480 cal BCE (6624 45 BP, LTL2656A, charcoal) (Dini, Fioravanti 2011). In southern and central Tuscany, with the exception of new dates from Giglio Island discussed below, the available dates concern Cardial aspects from the Tuscan Archipelago (Tozzi, Weiss 2001) which are rather late in the perspective of this paper; in addition, no SLS-date are available for these contexts. In Lazio, the lacustrine settlement of La Marmotta displayed different early pottery assemblages, including Impressa, whose clustering is debatable, and which did not provide SLS-dates (Fugazzola Delpino, Pessina 1999).

The situation in Campania is very challenging, with very early dates associated with diverse Impressa aspects probably connected to Apulia via the Ofanto valley, e.g., at Baselice (Langella et al. 2003) and at La Starza d'Ariano Irpino (Albore Livadie 2002); unfortunately, the associated dates are suspected of suffering from the old-wood effect.

In total, a set of 17 sites offering 94 AMS dates (Fig. 1 , Tab. 1) is considered here for a first appraisal of the earliest Neolithic dispersal from southern Italy and Corfu towards the North-West, using Bayesian modelling. Among these sites, when available, SLS- 
dates from the period immediately following (i.e. Red Painted Wares and Cardial) were used to provide constraints on the probabilities of the earlier dates. Controversial SLS-dates from Mesolithic Terragne (Gorgoglione et al. 1995) are also discussed infra.

To build this database, all material potentially affected by the marine or fresh-water reservoir effect, i.e. shells, was rejected. We kept the few $(n=5)$ directly dated human remains available from Pendimoun (early Cardial levels; Le Bras-Goude et al. 2006 ) and from Arma dell'Aquila (Impressa levels; Biagi, Starnini 2010), since stable isotopes indicate that none of them were questionable. Collagen samples from animal bones $(\mathrm{n}=14)$, including mostly domestic remnants, are also considered with a small risk, as the feeding of livestock with marine products (Balasse et al. 2005) was never evidenced in the region (Le Bras-Goude et al. 2006).

Considering charcoal, we have selected 10 dates, after rejecting long-lived tree samples (e.g., oak or juniper) whose anatomical characterisation (e.g., twigs or last rings samples) was not explicit. However, we kept, with question marks, a series of six unspecified charcoal samples from Trasanello due to the close connection of this site with Trasano. In addition, one date from Monochrome Sidari obtained on oak charcoal was used to constrain successive impressa deposits at this site. We also considered 58 dates from charred fruits and seeds, and primarily cereals, including husk.
We used Bayesian statistics through ChronoModel $\AA$ software, version 1.5 (Lanos, Philippe 2015a; 2015b; Lanos et al. 2015) and IntCal13 ${ }^{14} \mathrm{C}$ curve (Reimer et al. 2013) to model each site separately.

Similar methods have been classically applied using OxCal, for example, for the whole of Northern Italy (Pearce 2013) with consistent results at the general level, albeit with limited relevance due to the random intrinsic quality and stratigraphic accuracy of the samples.

ChronoModel software is based on the Bayesian event date model, which is aimed at estimating the date of a target event (Dean 1978) from the combination of individual dates derived from relevant dated events. This model has a hierarchical structure, which makes it possible to distinguish between a target event date (any date of interest for the archaeologist) and dates of events (artefacts) dated by chronometric methods, typo-chronology or historical documents. One assumes that these artefacts are all contemporaneous, which is relevant to the date of the target event. On the other hand, the dates can be affected by irreducible errors, hence the possible presence of outliers. To take into account these errors, the discrepancy between the chronometric dates and the target date is modelled by an individual variance, which allows the model to be robust to outliers, in the sense that individual variances act as outlier penalisation (Lanos, Philippe 2015a; $2015 b$ ). Thanks to this modelling, it is not necessary to discard outliers because the posterior (in the $\mathrm{Ba}$ -

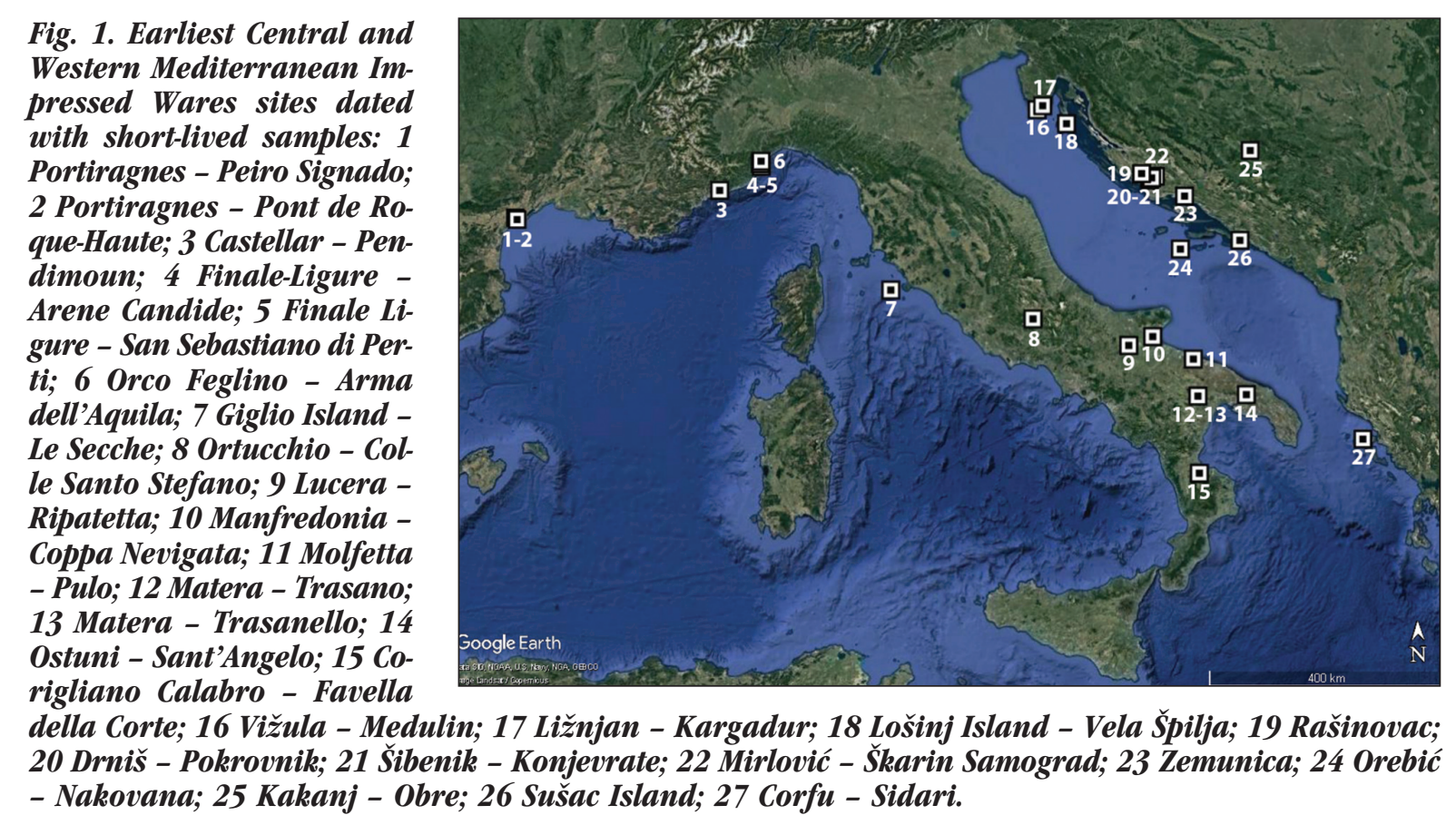


yesian sense) high values of the individual variances will automatically penalise their contributions to the estimate of event date.

Stratigraphic constraints, when available, are applied between event dates. Note that there is often only one chronometric date per target event date. Consequently, modelling makes sense only if there are order constraints between the event dates.

In ChronoModel, a phase is defined as a group of target event dates, with no statistical model. The group of events may belong either to a 'stratigraphic' phase defined as a group of ordered contexts, or to a 'chronological' phase defined as a set of contexts built on the basis of, inter alia, archaeological, architectural, geological, environmental criteria. In practice, a 'context' is defined by the nature of the stratification at a site, and the excavation approach used by the archaeologist. Together, these two phases determine the smallest units of space and time (i.e. the context) that can be identified in the stratigraphic record at an archaeological site. Some target events are then dated in these contexts.

We estimate the beginning, end and duration of a phase directly from the group of target dates, without adding any supplementary parametrisation.

Within 'multi-phase' sites, each chronological or cultural phase can include distinct clusters of stratigraphic units (Fig. 2) that could have been defined by spatial criteria, or in some cases, by the subdivision of a single phase deposits in distinct features directly (i.e. successive) or indirectly connected (e.g., covered by deposits from the following phase); in addition a single feature (e.g., stratigraphic unit) can provide one or several dates.

Within 'mono-phase' sites which display several features, constraints can be applied based on their relative chronology (e.g., overlapping) or their internal stratigraphic subdivisions; each one of the socalled events can provide one or several dates.

A few 'mono-phase' sites provide several available dates which are not connected as yet to defined features with an explicit relative chronology. In such cases, the different dates are considered as potentially different events included in a single phase.
For this paper, each site was modelled separately. As a result, the dates a posteriori for a multi-phase or mono-phase site are totally independent of those obtained from the others sites.

Each phase modelling is based on three runs of Markov's chains of 10000 iterations each. In order to compare the modelled phases, we calculated the probabilities of anteriority for each phase's beginnings compared to the others. For each couple of phase beginnings $[\Phi A \leq \Phi B]$, the distance is expressed as a percentage of the number of agreements (If $\mathrm{Ai} \leq$ $\mathrm{Bi}$ then agreement $=1$, otherwise agreement $=0$ for each iteration i). The phase classifications using these anteriority probabilities and using the modes $a$ posteriori (MAP) are similar, since the boundary distributions are mono-modal. This indicates that the MAP are very good representations of the relative position of the modelled boundaries of the different sites and phases (BMAP for the beginning and EMAP for the end of the considered phase). In this perspective, we assume that such representations are concepts, not values.

\section{Southern sites and samples}

The south-eastern dataset taken into consideration for this paper is composed of nine sites from the Ionian Islands, Apulia, Basilicata, Calabria and Abruzzo. It includes three multiphase sites (Pulo di Molfetta, Trasano and Trasanello), two mono-phase sites with several events (Coppa Nevigata and Favella della

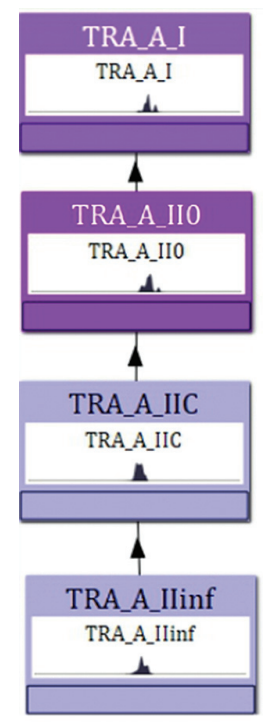

A

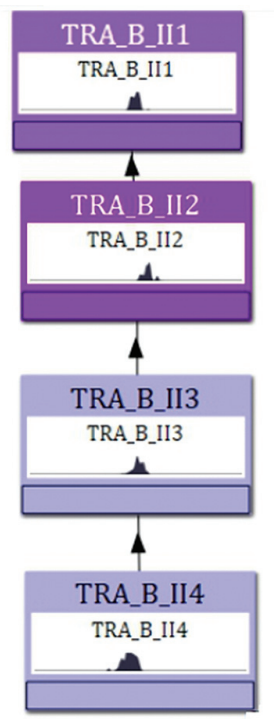

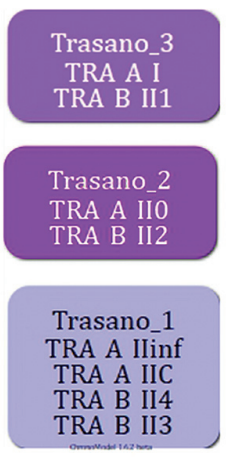

B

Fig. 2. Example of events (A) and phases (B) diagrams at Trasano (ChronoModel 1.5). Arrows indicate the stratigraphic constraints applied to the successive events; no constraints are applied between phases which are defined on stylistic criteria. 
Corte), two sites where single Impressa events within multiphase sites were SLS-dated (Ripatetta and Colle Santo Stefano) and two settlements with single SLS-dates from multiphase contexts (Sidari and Sant'Angelo di Ostuni). For the final discussion we also took into account the Pokrovnik series in Dalmatia, which offers a set of 12 SLS-dates for the stratified Impressa and Danilo deposits (McClure et al. 2014; Produg et al. on line).

At Sidari (Corfu), rescue excavations organised in 2004 provided a new stratigraphic record of the Holocene sequence (Berger et al. 2014; Sordinas 1967).

Above Mesolithic deposits which were partly reworked during the first half of the $7^{\text {th }}$ millennium, the Neolithic 'Monochrome', Phase 1 (US4a-b and pits F1 and F2), can be placed during the second half of the 7 th millennium at the earliest, thanks to seven AMS dates on oak charcoal. Neolithic Impressa, Phase 2 (US5b-c), provided a single SLS-date (one event). The more recent date from Phase 1 can be usefully considered as a terminus post quem for constraining the beginning of Phase 2 .

At the village of Pulo di Molfetta (Apulia), the excavation of Trench 3 in 1997-1999 allowed the recognition of three successive phases within the Neolithic deposits (Fiorentino et al. 2013; Muntoni 2003; 2009, Radina 2005). Phases I (US10 with two SLSdates available, US14 and 19) and II (US2 and 4) both belong to archaic Impressa, while Phase III (US9 and 17) belongs to the Serra d'Alto Culture (5 $5^{\text {th }}$ millennium). The further extension of Trench 3 in 2001, 2004 and 2007-2008 allowed the connection of US46 to Phase I and, directly above it, of US 49 to Phase II, each with one SLS-date available.

The Sant'Angelo cave (Ostuni, Apulia), known since the 1930s for the tremendous richness of its pottery deposits, was re-excavated in 1984 (Coppola 2001). Two SLS-dates are available from Level 9 (evolved Impressa, i.e. Guadone) and Levels 6-7 (late Impressa, i.e. Masseria La Quercia).

The enclosed village of Ripatetta (Apulia) was excavated between 1982 and 1992. Inside the ditch enclosure, a rectangular wattle-and-daub building was identified in sector A, while a wide rectangular cobble-paved area was identified within sector B. The latter are related to the evolved Impressa, i.e. Guadone, with unusual painted and red-slipped pots; they predate deposits from recent Impressa linked to the Lagnano-da-Piede style, which are not SLSdated as yet (Costantini, Stancanelli 1994; Tozzi 2002; Tozzi, Verola 1991). From two distinct parts of area B, three SLS-dates are available, clustered as two distinct events within the same phase.

Coppa Nevigata (Apulia) was considered an archetype of the archaic Impressa style, with closely paralleling pottery assemblages from Tremiti Islands and Pulo di Molfetta (Cassano, Manfredini 1987). Samples from Phase II-III provided a couple of SLSdates, both belonging to the archaic Impressa phase and considered as distinct events within a single phase.

The site at Terragne (Apulia), excavated by M. Gorgoglione in 1985-1991, yielded a Neolithic deposit attributed to the evolved and final Impressa (US3) above a layer devoid of pottery and whose lithic series suggested a Late Mesolithic occupation (US4-5). The latter could be currently the sole Late Mesolithic settlement from southern Italy providing SLS-dates (Gorgoglione et al. 1995); those two samples from wild fauna collagen are included as distinct events in a single phase, although their attribution to the Mesolithic is controversial.

Trasano (Basilicata), excavated by Jean Guilaine and Giuliano Cremonesi between 1984 and 1991, is a key enclosed village providing a clear succession of the three Impressa aspects: archaic, evolved and recent (Angeli 2012; Guilaine, Cremonesi 1987; Radi et al. 2000).

Following a first set of dates with large standard errors, and the implementation of alternative methods to radiocarbon (e.g., Vartanian et al. 2000), new AMS dates were obtained from sectors A and B. Within each one, four SLS-dates were obtained, as yet unpublished: Sector A: archaic (C2inf beneath C2c), evolved (C2.0) and recent (C1); Sector B: archaic (C2.4 beneath C2.3), evolved (C2.2) and recent (C2.1).

At Trasanello Cementificio (Basilicata), at approx. $1200 \mathrm{~m}$ from Trasano, detailed stratigraphy has been recorded within Trench 11 in 2011 (Angeli 2012). A final Impressa occupation (US5 with four dates corresponding to different contemporary contexts) predates the Red Painted Wares (US3 with two superposed dated samples). Although unspecified charcoal was used, these dates, as yet unpublished, were taken into account in this paper regarding their connection with recent Impressa at Trasano. 
Favella della Corte (Calabria) is a remarkable village, excavated from 1990 to 2002. The settlement, dated to the archaic phase, has a large set of pits considered as mono-phase, with partly staggered multi-events. Pottery analysis suggests a slight evolution of the archaic assemblages from structures A and D towards structures E and G (Tiné 2009). From this site, six SLS-dates are available from Structure A (middle part of Pit Z, US4), Structure D (bottom and top of Pit Y, US4), Structure E (Pit 30, US4, predating Pit T, US3) and Structure G (Pit 10, US3).

The village of Colle Santo Stefano (Abruzzo) offers multiphase stratigraphy covering the evolved Impressa aspects. This designates the site as the first pioneer settlement to be identified so far in Central Italy that was connected with the evolved Guadone aspects from the South-East. The earliest occupation is characterised by a cobble-paved area (US17) and the successive episodes (US8 and US3) provide diverse dated features (Fabbri et al. 2011; Radi et al. 2001). A set of eight overlapping dates on charcoal suggested less than four centuries for the whole occupation. A couple of new SLS-dates were run on samples from the same event within the earliest deposits.

\section{North-western sites and samples}

The north-western dataset is composed of two multiphase sites (Arene Candide and Pendimoun), one multi-event within the deposits of a mono-phase site (Pont de Roque-Haute) and one mono-phase site for which no distinct events have been recorded (Peiro Signado).

In addition, three sites are useful for the final discussion, although they provided SLS-dates which are not strictly connected to stratigraphic series and/or to stylistic phases (Le Secche, San Sebastiano di Perti and Arma dell'Aquila).

At Le Secche (Giglio Island, Tuscan archipelago), a thick deposit with abundant pottery and lithic series filled a narrow joint in a context of typical eroded granite 'marbles'. The Impressa pottery assemblage consists mainly of sherds offering parallels with the south-eastern archaic style, and a smaller set of later remains (e.g., probably later Cardial, Linear pottery and Diana sherds) (Brandaglia 1991; 2002).

In 2016, new sampling of in situ deposits allowed AMS dating. Unfortunately, the samples were not found in a stratigraphic context and the three SLSdates have to be included within a single generic cluster.

The vast cave of Arene Candide (western Liguria) is well known for its extended stratigraphic record of Upper Palaeolithic and Neolithic settlement (Branch et al. 2014; Maggi 1997a). For various reasons mainly the excavation of extended stratigraphic units lying over wide areas - the ICC periodisation from Bernabò Brea's and Tiné's operations has been debated since vertical movements of pottery were observed in different sectors of the site (Biagi, Starnini 2016; Del Lucchese, Starnini 2010; Maggi 1997b). The Neolithic chronology has improved thanks to new fieldwork adjacent to Tiné's operation carried out in 1997 (Binder, Maggi 2001), 2002 and more intensively in 2012 (Arobba et al. 2017); both operations provided accurate stratigraphic control and recording.

Within Maggi's 1997-2002 sector, Impressa was found in two successive units (US10 and 10A with four SLS-dates under US.9Bbase with one SLS-date) and predating the Cardial deposits (US9B with one SLS-date). Within the 2012 area, R. Maggi, C. Panelli and S. Rossi clustered the ICC deposits into nine sets; among them, Impressa was associated with Phase AC1 at the bottom (from sets 2 to 4 including, US360 at the bottom, US347, US351A and US330 at the top, with four SLS-dates); early Cardial aspects define Phase AC2 (from sets 5 to 7, including US312, with two SLS-dates). In addition, a date has been obtained for the charred remains included in a typical Cardial pot from Phase AC2, with refitted sherds from set 6 and from Layer 26 of Bernabò Brea's excavations (Arobba et al. 2017).

At San Sebastiano di Perti (western Liguria) in 1992, a deposit preserved on a small terrace produced a sherd set that included diverse types of Impressed wares and charred seeds (Biagi, Starnini 2016; Capelli et al. 2006; Starnini, Vicino 1993). From this unique layer, three SLS-dates are to be considered as distinct events clustered in a single generic set.

Arma dell'Aquila (western Liguria), excavated in 1938-1942 by C. Richard, revealed a set of burials and human remains in a context where diverse Neolithic aspects were identified, which included Impressed wares (Biagi, Starnini 2016). Two skull fragments, from a child burial and from Layer 7 , respectively, provided SLS-dates, here considered as distinct events included in a single generic phase. 
Pendimoun (eastern Provence) is a large rock-shelter whose stratigraphy recorded a large part of the Neolithic period. Taking advantage of the preliminary results obtained in 1985-1992 (Binder et al. 1993), more extended excavations were organised in 1998-2006 in both the northern and southern sectors, separated by the trench dug in the 1950s (Battentier et al. 2015; Binder, Sénépart 2010).

Within the northern sector, the Impressa set encompasses several stratigraphic units and features of small size (including nine SLS-dates from five events: US2067, 41678, 47800 and 47801) which predate early Cardial units (including 10 SLS-dates from seven events: burials F1 and H2, US18364, 19000 , 19001 and 42370 ); US47799 is a technical unit situated at the interface between Impressa ( $\# 47889$ ) and Cardial (\#48 256) phases. Within the southern sector, the Impressa set also contains several units (including four SLS-dates from four events: US5711, 28889,29203 and base of US28 781\#28 905) which also predate the early Cardial units (including two SLS-dates from two events: burial F1 and the top of US28 781\#28 898). Current research is focused on the correlation of both sectors, since Impressa pottery assemblages differ slightly from one to another.

Pont de Roque-Haute (Mediterranean Languedoc) is a small open-air settlement with ten pits of different shapes. The consistent pottery assemblage is considered as mono-phase and, on the basis of its parallels with Le Secche, linked to the south-eastern Italian tradition (Guilaine et al. 2007). A set of five SLS-dates from pit F1, which is the richest, is here clustered into two successive events (two from F1 base and three from F1) belonging to a single phase.

Peiro Signado (Mediterranean Languedoc), excavated in 1978 and 1996-1997, yielded the remains of an oval building and a set of adjacent pits (Briois, Manen 2009; Briois et al. 2009; Roudil, Soulier 1981). As yet, the extremely abundant pottery assemblage associated with the archaeological features is considered as belonging to a unique phase. Then the two available SLS-samples are here clustered as distinct events within a single phase.

\section{Modelling results and interpretations}

\section{The early southern and central Italian chro-} nology (Tabs. 2, 3 and 4, Fig. 3)

The probability of Favella's beginning to predate $\mathrm{Pu}$ lo's is very weak ( $53 \%)$. The modelled dates from both sites indicate that the Archaic Impressa stage could have begun during the second half of the $60^{\text {th }}$ century (BMAP: 5918 and 5953 BCE respectively) and slightly post-date the earliest southern Dalmatian Impressa, e.g., from Pokrovnik (BMAP: 5978 BCE).

The two SLS-dates obtained for Terragne-US4-5 (BMAP: 6138 BCE; EMAP: 5804 BCE) are not accurate enough to support a secure Late Mesolithic attribution.

The single Impressa date from Sidari-5cd (event HPD: 6191-5885 BCE) could be placed over these boundaries, as the previous Monochrome phase Sidari- 4 seems so far to have developed until the end of the $7^{\text {th }}$ millennium (event_HPD: 6557-6019 BCE).

Trasano 1 and Coppa Nevigata settlements seem to have begun a century later (BMAP: 5823 and 5810 BCE, respectively). The whole dataset indicates that the archaic phase could have lasted three centuries, until the very beginning of the $57^{\text {th }}$ century (EMAP: from 5704 to 5682). These results give us an idea of an internal periodisation of the archaic stage. Furthermore, the marked differences observed between Trasano 1, where tool impressions predominate $(c$. $65 \%$ ), and Favella, where finger and nail impressions predominate ( $42 \%$ ), support the idea of different stylistic traditions within the archaic stage. Nevertheless, as already suggested by Elena Natali and Vincenzo Tiné (Tiné 2009), our modelling does not support the idea of an internal evolution from one sector of the site to the other.

New modelled dates of Ripatetta confirm that the evolved Impressa, i.e. the Guadone style, clearly overlap the second part of the archaic phase (BMAP: 5841 BCE). The precocity of the Guadone aspect at Ripatteta illustrates the huge variability of pottery production during the $59^{\text {th }}$ and $58^{\text {th }}$ centuries in a rather small area; this raises new issues on the social origin of such discrepancies and, moreover, the increasing role of crafts and workshops. The single event dated at Sant'Angelo and its debated pottery assemblage providing both archaic and evolved aspects could have taken place in such a context.

The modelled dates highlight the very good seriation of archaic, evolved and recent stages of the Impressa in the Basilicata, at Trasano, during three centuries, until the end of the 56th (EMAP: $5588 \mathrm{BCE}$ ). Here the evolved and recent phases seem brief, approximately one century. Nevertheless, the earliest 


\begin{tabular}{|c|c|c|c|c|c|}
\hline Event (n-dates) & e_HPD (95\%) & e_MAP & Event (n-dates) & e_HPD (95\%) & e_MAP \\
\hline Terragne_US4-5\#2 (1) & {$[-6132 ;-5510]$} & -5803 & Trasano_B_II3 (1) & {$[-5823 ;-5649]$} & -5721 \\
\hline Terragne_US4-5\#1 (1) & {$[-6398 ;-5857]$} & -6137 & Trasano_A_IIC (1) & {$[-5756 ;-5633]$} & -5691 \\
\hline Sidari_Fo4 (1) & {$[-6557 ;-6019]$} & -6250 & Trasano_B_II4 (1) & {$[-6006 ;-5705]$} & -5821 \\
\hline Sidari_Hearth5b-5c (1) & {$[-6191 ;-5885]$} & -6033 & Trasano_A_Ilinf (1) & {$[-5884 ;-5665]$} & -5733 \\
\hline Pulo_II_US49 (1) & {$[-5695 ;-5424]$} & -557 & Trasanello_US3sup (1) & {$[-5431 ;-5083]$} & -5269 \\
\hline Pulo_Isup_US46 (1) & {$[-5824 ;-5554]$} & -5682 & Trasanello_US3inf (1) & {$[-5585 ;-5368]$} & -5510 \\
\hline Pulo_linf_USıO (2) & {$[-6078 ;-5790]$} & -5953 & Trasanello_US5_Foss (1) & {$[-5711 ;-5461]$} & -5578 \\
\hline S. Angelo_T6-7 (1) & {$[-5729 ;-5242]$} & -5502 & Trasanello_US5_C4 (1) & {$[-5716 ;-5473]$} & -5587 \\
\hline S. Angelo_T9 (1) & {$[-6151 ;-5599]$} & -5861 & Trasanello_US5_B3 (1) & {$[-5757 ;-5495]$} & -5607 \\
\hline Ripatetta_Acciottolato_C9 (1) & {$[-6049 ;-5521]$} & -5769 & Trasanello_US5_cv (1) & {$[-5722 ;-5477]$} & -5585 \\
\hline Ripatetta_Acciottolato_IM30 (2) & {$[-5949 ;-5715]$} & -5812 & Favella_StrE_FoT-US3 (י) & {$[-5963 ;-5435]$} & -5755 \\
\hline Coppa Nevigata_II-III_\#A (1) & {$[-6083 ;-5458]$} & -5740 & Favella_StrG-Fo1o-US3-VI (1) & {$[-6150 ;-5625]$} & -5889 \\
\hline Coppa Nevigata_II-III_\#B (1) & {$[-6124 ;-5425]$} & -5767 & Favella_StrD-FoY-US4-II (1) & {$[-5790 ;-5568]$} & -5680 \\
\hline Trasano_B_Il1 (1) & {$[-5718 ;-5489]$} & -5638 & Favella_StrA-FoZ-US4-VI (1) & {$[-6070 ;-5549]$} & ] -5793 \\
\hline Trasano_A_I (1) & {$[-5683 ;-5464]$} & -5620 & Favella_StrE-Fo3o-US4-II (1) & {$[-6080 ;-5652]$} & -5823 \\
\hline Trasano_B_II2 (1 & {$[-5743 ;-5591]$} & -5663 & Favella_StdD-FoY-US4-XIII (1) & {$[-6004 ;-5682]$} & -5820 \\
\hline Trasano_A_Ilo (1) & {$[-5713 ;-5575]$} & -5646 & Colle-S.Stefano_17 (2) & {$[-5750 ;-5616]$} & -5683 \\
\hline
\end{tabular}

Tab. 2. Modelled events (from Table 1) of southern and central Italian ICC. The number of associated dates for each event is indicated in brackets: $e_{-} H P D(95 \%)$, i.e. the event's highest posterior density interval at 95\% confidence; $e_{-} M A P$, event's posterior mode.

deposits from Trasanello 1 (BMAP: 5629 BCE; EMAP: 5542 BCE), attributed to the final phase and predating the development of Red Painted Wares, slightly overlap Trasano 3, which raises questions about possible old-wood effect.

The place occupied by the Stentinello aspects is still challenging due to the lack of SLS-dates and stratigraphic seriations, in Sicily and Calabria as well. The single date from Piana di Curinga was obtained from an excellent context on a pole from the wattle-anddaub house $\mathrm{H}$, but with a possible old-wood effect (Ammerman et al. 1988).
Thanks to a single event dated at Colle Santo Stefano (e_HPD: 5750-5616 BCE), the modelling confirms that Neolithic diffusion towards Central Italy is rather late, between the mid-58th and the very end of the $57^{\text {th }}$ century, contemporary with the end of Ripatetta's evolved Impressa and the beginning of evolved Impressa aspects at Trasano 2. However, additional SLS-dates from the successive phases recorded at Colle Santo Stefano are necessary for a better understanding of the regional trend and the transition to the latest aspects of Medio-Adriatic Impressa during the second part of the $6^{\text {th }}$ millennium.

\begin{tabular}{|lcccccc|}
\hline Phase (n-events, n-dates) & D_HPD (95\%) & D_MAP & B_HPD (95\%) & B_MAP & E_HPD (95\%) & E_MAP \\
\hline Terragne_Late Mesolithic ? (2, 2) & {$[1 ; 626]$} & 327 & {$[-6398 ;-5875]$} & -6138 & {$[-6108 ;-5530]$} & -5804 \\
\hline Pulo-1_Archaic-Imp $(2,3)$ & {$[50 ; 441]$} & 257 & {$[-6078 ;-5790]$} & -5953 & {$[-5824 ;-5554]$} & -5682 \\
\hline Favella_Archaic-Imp $(6,6)$ & {$[87 ; 705]$} & 248 & {$[-6205 ;-5792]$} & -5918 & {$[-5776 ;-5383]$} & -5669 \\
\hline Favella_2_Archaic-Imp $(2,2)$ & {$[0 ; 505]$} & 107 & {$[-6123 ;-5685]$} & -5890 & {$[-5930 ;-5428]$} & -5753 \\
\hline Favella_1_Archaic-Imp $(4,4)$ & {$[33 ; 570]$} & 201 & {$[-6189 ;-5737]$} & -5872 & {$[-5788 ;-5523]$} & -5679 \\
\hline Trasano-1_Archaic-Imp $(4,2)$ & {$[18 ; 348]$} & 138 & {$[-6024 ;-5722]$} & -5823 & {$[-5740 ;-5633]$} & -5686 \\
\hline Coppa-Nevigata_Archaic-Imp (2, 2) & {$[0 ; 511]$} & 56 & {$[-6141 ;-5607]$} & -5810 & {$[-5935 ;-5399]$} & -5704 \\
\hline Ripatetta_Evolved-Imp $(2,3)$ & {$[0 ; 312]$} & 40 & {$[-6005 ;-5726]$} & -5841 & {$[-5901 ;-5566]$} & -5771 \\
\hline Trasano-2_Evolved-Imp (2, 2) & {$[1 ; 115]$} & 15 & {$[-5738 ;-5622]$} & -5671 & {$[-5695 ;-5567]$} & -5641 \\
\hline Trasano-3_Recent-Imp $(2,2)$ & {$[0 ; 207]$} & 23 & {$[-5701 ;-5561]$} & -5637 & {$[-5664 ;-5413]$} & -5588 \\
\hline Trasanello-1_Late-Imp (4, 4) & {$[1 ; 304]$} & 87 & {$[-5850 ;-5552]$} & -5629 & {$[-5611 ;-5470]$} & -5542 \\
\hline Trasanello-2_Bande Rosse (2, 2) & {$[16 ; 396]$} & 221 & {$[-5585 ;-5368]$} & -5510 & {$[-5431 ;-5083]$} & -5269 \\
\hline
\end{tabular}

Tab. 3. Modelled phases of southern and central Italian ICC. The number of associated events and dates for each phase is indicated in brackets: D_HPD (95\%), highest posterior density interval at 95\% confidence of phase duration; D_MAP, posterior mode of phase duration; B_HPD (95\%), highest posterior density interval at 95\% confidence of phase beginning; $B \_M A P$, posterior mode of phase beginning; E_HPD (95\%), highest posterior density interval at 95\% confidence of phase's end; E_MAP, posterior mode of phase's end. 
The Impressa spread towards the North-West and its evolutionary trends (Tabs. 5-7, Fig. 4) Compared to Abruzzo, which offers the earliest available dates for Central Italy, the first evidence of Neolithic settlement is very early, at least one century earlier, in the North-West and at the latest during the transition between the 59th and $58^{\text {th }}$ centuries, at least two centuries before the Iberian Peninsula (Isern et al. 2017; Zilhão 2001).

For the North-Western Mediterranean, the modelled dates indicate a rather good seriation of the sites and

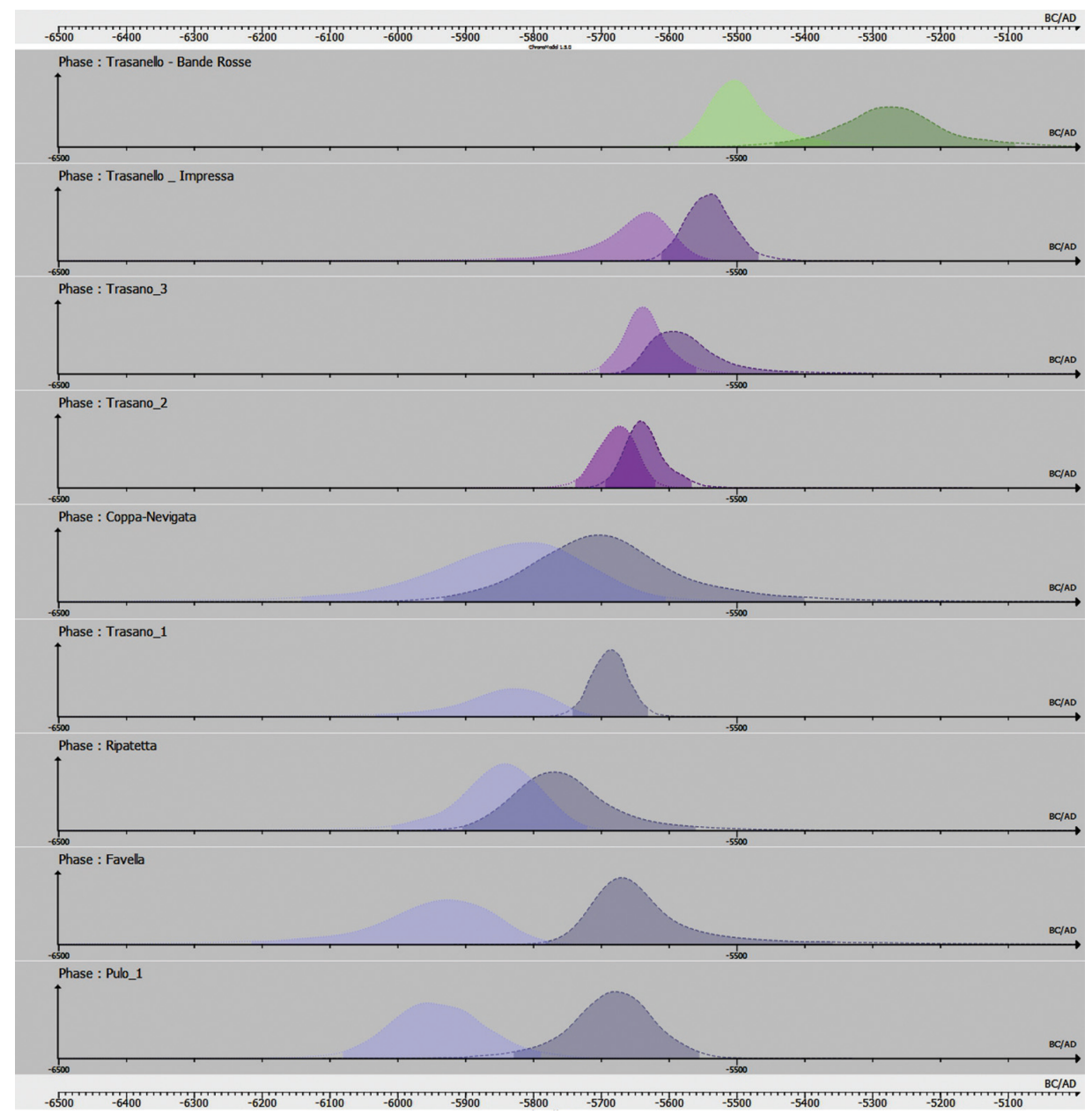

Fig. 3. Posterior density distribution of all south-eastern Italian Impressa phases. The density region of the beginnings are the oldest. The areas below the curves represent the 95\% highest posterior densities.

\begin{tabular}{|c|c|c|c|c|c|c|c|c|c|}
\hline & 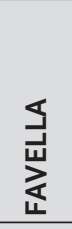 & 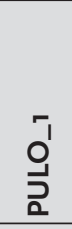 & 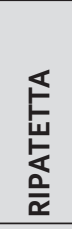 & 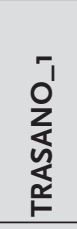 & 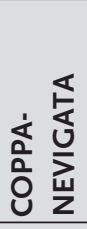 & 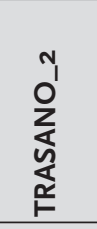 & 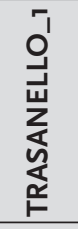 & 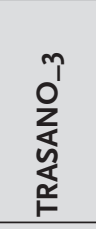 & 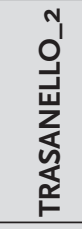 \\
\hline FAVELLA & & 52,7 & 82,3 & 82,5 & 77,7 & 100,0 & 97,5 & 100,0 & 100,0 \\
\hline PULO_1 & 47,3 & & 81,1 & 81,2 & 76,4 & 99,9 & 97,2 & 100,0 & 100,0 \\
\hline RIPATETTA & 17,7 & 18,9 & & 52,9 & 55,4 & 99,7 & 94,9 & 100,0 & 100,0 \\
\hline TRASANO_1 & 17,5 & 18,8 & 47,1 & & 53,6 & 100,0 & 94,6 & 100,0 & 100,0 \\
\hline COPPA-NEVIGATA & 22,3 & 23,6 & 44,6 & 46,4 & & 92,8 & 90,2 & 97,0 & 99,8 \\
\hline TRASANO_2 & 0,0 & 0,1 & 0,3 & 0,0 & 7,2 & & 66,5 & 100,0 & 100,0 \\
\hline TRASANELLO_1 & 2,5 & 2,8 & 5,1 & 5,4 & 9,8 & 33,5 & & 59,4 & 100,0 \\
\hline TRASANO_3 & 0,0 & 0,0 & 0,0 & 0,0 & 3,0 & 0,0 & 40,6 & & 99,2 \\
\hline TRASANELLO_2 & 0,0 & 0,0 & 0,0 & 0,0 & 0,2 & 0,0 & 0,0 & 0,8 & \\
\hline
\end{tabular}

Tab. 4. Anteriority probabilities of phase beginnings for the southern and central Italian ICC (expressed in percentages). The higher the probability, the greater the distance. 
of the main pottery styles, although many questions remain unsolved.

Obviously, the pottery style of Peiro Signado (BMAP: 5826 BCE) and Arene Candide (BMAP: 5786 BCE), characterised by the predominance of stab-and-drag decoration, is currently the marker of the first Neolithic impact in the North-West, although its links with the South-East are weak, since almost no direct stylistic comparison can be established with either the archaic or the Guadone style, both contemporary. Some comparisons are still to be sought in Sicily and Calabria, within Stentinello sensu lato (Bernabò Brea 1950; Scarcella 2011).

The beginnings of the Pont de Roque-Haute aspects (BMAP: 5767 BCE) cannot be distinguished from Peiro Signado and Arene Candide, although they could be more clearly linked to the archaic style of the South-East, for instance Trasano 1, via Giglio in the Tuscan archipelago. Unfortunately, the dates from Giglio are not a great help: they appear to be rather late (BMAP: $5674 \mathrm{BCE}$ ) compared to the earliest dispersal, and their reliability to one or another style present within the pottery assemblage is weak. The shared use of obsidian from Palmarola and Sardinia adds to the general consistency of these earliest northern styles, which at the moment have to be kept in the same set.

\begin{tabular}{|lll|}
\hline Event (n-dates) & e_HPD (95\%) & e_MAP \\
\hline Giglio-Secche_\#3 (1) & {$[-5706 ;-5186]$} & -5450 \\
\hline Giglio-Secche_\#1 (1) & {$[-5742 ;-5409]$} & -5579 \\
\hline Giglio-Secche_\#2 (1) & {$[-5820 ;-5534]$} & -5669 \\
\hline Arene-Candide_US9B (1) & {$[-5544 ;-5155]$} & -5351 \\
\hline Arene-Candide_Cardial pot (1) & {$[-5590 ;-5234]$} & -5417 \\
\hline Arene-Candide_US312 (2) & {$[-5620 ;-5196]$} & -5291 \\
\hline Arene-Candide_US9Bbase (1) & {$[-5704 ;-5489]$} & -5625 \\
\hline Arene-Candide_US330 (1) & {$[-5747 ;-5467]$} & -5657 \\
\hline Arene-Candide_US10 (1) & {$[-5776 ;-5616]$} & -5704 \\
\hline Arene-Candide_US347 (1) & {$[-5772 ;-5592]$} & -5685 \\
\hline Arene-Candide_US351A (1) & {$[-5809 ;-5628]$} & -5712 \\
\hline Arene-Candide_US10A (2) & {$[-5842 ;-5686]$} & -5748 \\
\hline Arene-Candide_US360 (1) & {$[-5972 ;-5676]$} & -5771 \\
\hline S. Sebastiano Perti_\#1 (1) & {$[-5730 ;-5472]$} & -5586 \\
\hline S. Sebastiano Perti_\#2 (1) & {$[-5813 ;-5517]$} & -5664 \\
\hline S. Sebastiano Perti_\#3 (1) & {$[-5800 ;-5537]$} & -5672 \\
\hline Aquila_\#1 (1) & {$[-5731 ;-5471]$} & -5587 \\
\hline Aquila_\#2 (1) & {$[-5730 ;-5464]$} & -5584 \\
\hline Pendimoun_N_US.18364 (2) & {$[-5400 ;-5146]$} & -5326 \\
\hline Pendimoun_N_US.19000 (1) & {$[-5415 ;-5224]$} & -5342
\end{tabular}

The deposits and pottery production of Pendimoun cover a wide range, more than two centuries, starting at the very end of the $58^{\text {th }}$ century in the southern sector (BMAP: $5715 \mathrm{BCE}$ ). It has virtually no stylistic connections with Arene Candide 1A, which is definitely earlier, and more consistent with Arene Candide 1B (event_HPD: 5704-5489). Surprisingly strong comparisons can be made with the archaic aspect of Favella that could have ended in the middle of the $57^{\text {th }}$ century, with a similar proportion of finger and nail impressions. Later assemblages from the northern sector of Pendimoun (BMAP: 5608 BCE) can be connected with several sites in Liguria, including Arma dell'Aquila (BMAP: 5619 BCE), which offers some stylistic parallels, e.g., small curvilinear impressions. All these aspects predate with a high probability the Cardial phases at Pendimoun (BMAP: 5503 and 5445 BCE) and Arene Candide 2 (BMAP: 5467 BCE).

\section{Dispersal routes and speed, and the endless question of origins}

Regarding the distance, approx. $1500 \mathrm{~km}$ of coastline, the spread from the South to the North-West occurred at a record speed, as the difference of BMAP between the earliest southern sites (Pulo di Molfetta or Favella) and the earliest northern one (Peiro Signado) is in the order of one century (Figs. 5-6). This confirms and specifies previous considerations that were based on a smaller set of less accurate radio-

Tab. 5. Modelled events (from Table 1) of the north-western Mediterranean ICC. The number of associated dates is for each event indicated in brackets: $e_{-}$HPD (95\%), i.e. event's highest posterior density interval at 95\% confidence; $e_{-}$MAP, event's posterior mode. 


\begin{tabular}{|lcccccc}
\hline Phase (n-events, n-dates) & D_HPD (95\%) & D_MAP & B_HPD (95\%) & B_MAP & E_HPD (95\%) & E_MAP \\
\hline PeiroSignado $(2,2)$ & {$[1 ; 329]$} & 38 & {$[-6034 ;-5703]$} & -5826 & {$[-5895 ;-5562]$} & -5763 \\
\hline Arene-Candide-1A_Impressa $(6,7)$ & {$[40 ; 410]$} & 154 & {$[-5963 ;-5707]$} & -5786 & {$[-5726 ;-5473]$} & -5653 \\
\hline Pont-de-Roque-Haute $(2,5)$ & {$[0 ; 109]$} & 12 & {$[-5857 ;-5711]$} & -5767 & {$[-5805 ;-5677]$} & -5739 \\
\hline Pendimoun-S_Impressa $(4,6)$ & {$[18 ; 315]$} & 121 & {$[-5881 ;-5633]$} & -5715 & {$[-5671 ;-5499]$} & -5611 \\
\hline S. Sebastiano Perti_Impressa/Cardial $(3,3)$ & {$[2 ; 293]$} & 103 & {$[-5841 ;-5609]$} & -5697 & {$[-5682 ;-5458]$} & -5581 \\
\hline Giglio_Impressa/Cardial $(3,3)$ & {$[34 ; 498]$} & 210 & {$[-5837 ;-5544]$} & -5674 & {$[-5627 ;-5237]$} & -5456 \\
\hline Aquila_Impressa (2, 2) & {$[1 ; 204]$} & 23 & {$[-5739 ;-5528]$} & -5619 & {$[-5654 ;-5447]$} & -5571 \\
\hline Pendimoun-N_Impressa $(5,9)$ & {$[50 ; 299]$} & 147 & {$[-5737 ;-5532]$} & -5608 & {$[-5516 ;-5387]$} & -5470 \\
\hline Pendimoun-N_Cardial $(7,10)$ & {$[77 ; 385]$} & 189 & {$[-5609 ;-5424]$} & -5503 & {$[-5400 ;-5146]$} & -5326 \\
\hline Arene-Candide-2_Cardial $(3,4)$ & {$[13 ; 376]$} & 149 & {$[-5625 ;-5332]$} & -5467 & {$[-5458 ;-5131]$} & -5298 \\
\hline Pendimoun-S_Cardial $(2,2)$ & {$[1 ; 237]$} & 26 & {$[-5599 ;-5323]$} & -5445 & {$[-5487 ;-5196]$} & -5364 \\
\hline
\end{tabular}

Tab. 6. Modelled phases of the north-western Mediterranean ICC. The number of associated events and dates for each event is indicated in brackets: D_HPD (95\%), highest posterior density interval at 95\% confidence of phase duration; D_MAP, posterior mode of phase duration; B_HPD (95\%), highest posterior density interval at 95\% confidence of phase beginning; $B$ _MAP, posterior mode of phase beginning; $E_{-}$HPD (95\%), highest posterior density interval at 95\% confidence of phase's end; $E_{-}$MAP, posterior mode of phase's end.

carbon dates (Binder, Guilaine 1999; Zilhão 2001). Our results contribute to moderating, and even to changing, the idea of a strong contrast between a fast continental farming dispersal following rivers (i.e. trans-Balkans routes) and a slow one following maritime itineraries (i.e. Adriatic routes) (Biagi et al. 2005). Indeed, the dispersal from southern Italy towards Liguria and France appears seven or eight times faster than for reaching Abruzzo.

Within this Ulyssean world, voyagers faced many hazards, depending on their own sailing skills. Surface currents could have been a compelling factor limiting voyaging capacities, and this could partly explain the apparent discontinuity of the north-western spread and the lack of early sites in several regions (e.g., Lazio, Tuscany or Sardinia on the west- ern slope of the Apennine, or Molise, Umbria, Abruzzo, Emilia etc. on the eastern slope).

In the Alps, the Tosco-Emilian Apennine and the Po plain, a significant network of Late Mesolithic settlements is observed (Ferrari 2010; Franco 2011; Marchand, Perrin 2017) which is not the case everywhere in the North-Western Mediterranean and especially in places where the farmers first settled (Western Liguria, Eastern Provence, Mediterranean Languedoc). Although the Castelnovian chronology is still poorly known in general terms, late Mesolithic sites, contemporary with the first evidence of farmer settlement, are documented in the Rhône Valley and in the Tosco-Emilian Apennine (Binder et al. 2017; Dini, Fioravanti 2011; Marchand, Perrin 2017). This has sometimes been considered to be

\begin{tabular}{|c|c|c|c|c|c|c|c|c|c|}
\hline & 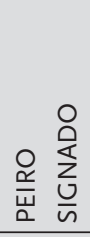 & 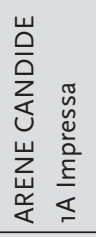 & 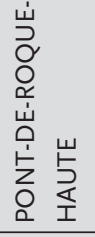 & 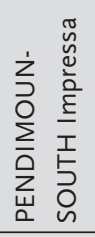 & 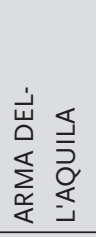 & 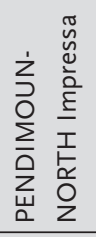 & 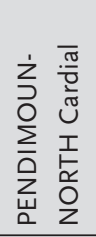 & 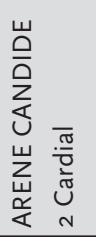 & 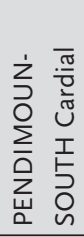 \\
\hline PEIRO SIGNADO & & 63,9 & 79,7 & 88,4 & 98,1 & 98,1 & 100,0 & 99,5 & 100,0 \\
\hline ARENE CANDIDE ıA Impressa & 36,1 & & 68,0 & 84,3 & 97,8 & 97,8 & 100,0 & 99,4 & 100,0 \\
\hline PONT-DE-ROQUE-HAUTE & 20,3 & 32,1 & & 77,5 & 97,0 & 97,1 & 100,0 & 99,3 & 100,0 \\
\hline PENDIMOUN-SOUTH Impressa & 11,6 & 15,7 & 22,5 & & 93,5 & 93,6 & 99,9 & 99,0 & 100,0 \\
\hline ARMA DELL'AQUILA & 1,9 & 2,2 & 3,0 & 6,5 & & 52,9 & 96,3 & 94,3 & 98,4 \\
\hline PENDIMOUN-NORTH Impressa & 1,9 & 2,2 & 2,9 & 6,4 & 47,1 & & 100,0 & 94,1 & 98,4 \\
\hline PENDIMOUN-NORTH Cardial & 0,0 & 0,0 & 0,0 & 0,1 & 3,7 & 0,0 & & 64,3 & 83,5 \\
\hline ARENE CANDIDE 2 Cardial & 0,5 & 0,6 & 0,7 & 1,0 & 5,7 & 5,9 & 35,7 & & 65,2 \\
\hline PENDIMOUN-SOUTH Cardial & 0,0 & 0,0 & 0,0 & 0,0 & 1,6 & 1,6 & 16,6 & 34,8 & \\
\hline
\end{tabular}

Tab. 7. Anteriority probabilities of phase beginnings for the north-western Mediterranean ICC (expressed in percentages). The higher the probability, the greater the distance. 
at the origin of a lock for the ICC dispersion (Binder 2000; 2013).

As yet, the absence of Mesolithic data prevents a discussion of such a hypothesis for the eastern slopes of the central Apennine. Thus the question of a blocking situation of the Neolithic spread on the western side of the Adriatic remains wide open, unlike what is observed on the eastern shore (Biagi et al. 2005).

The diversity observed in the earliest ICC from the northern Mediterranean reflects parts of the diversity observed in the South-East. This could have resulted from the diffusion of small culturally diverse

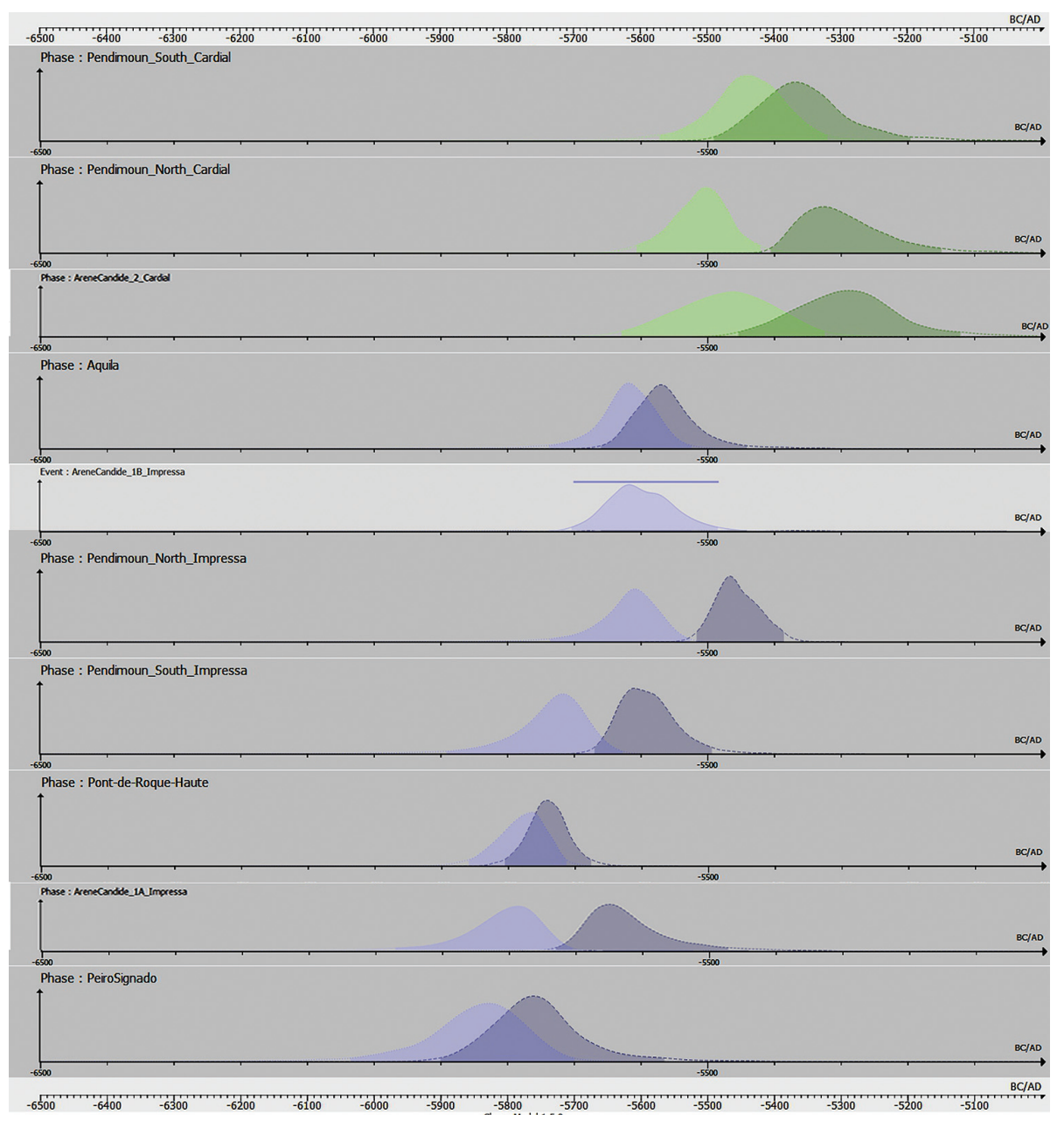

Fig. 4. Posterior density distribution of all north-western Impressa phases. The density region of the beginnings are the oldest. The areas below the curves represent the 95\% highest posterior densities.

Fig. 5. Representation of the earliest Italian and northwestern Mediterranean ICC settlements using the Mode a posteriori of Phases beginning (BMAP): AC Arene Candide; CN Coppa Nevigata; CSS Colle Santo Stefano; FC Favella della Corte; GS Giglio Le Secche; PE Pendimoun; PM Pulo di Molfetta; PRH Pont de Roque-Haute; PS Peiro Signado; RT Ripatetta; TR Trasano.

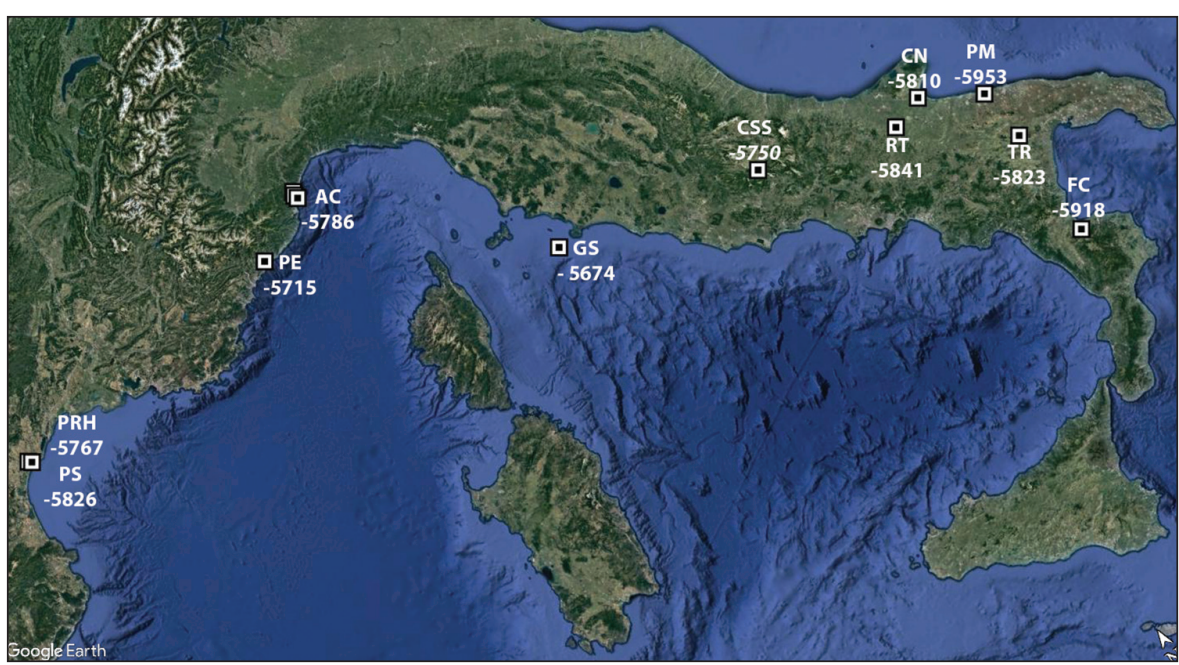




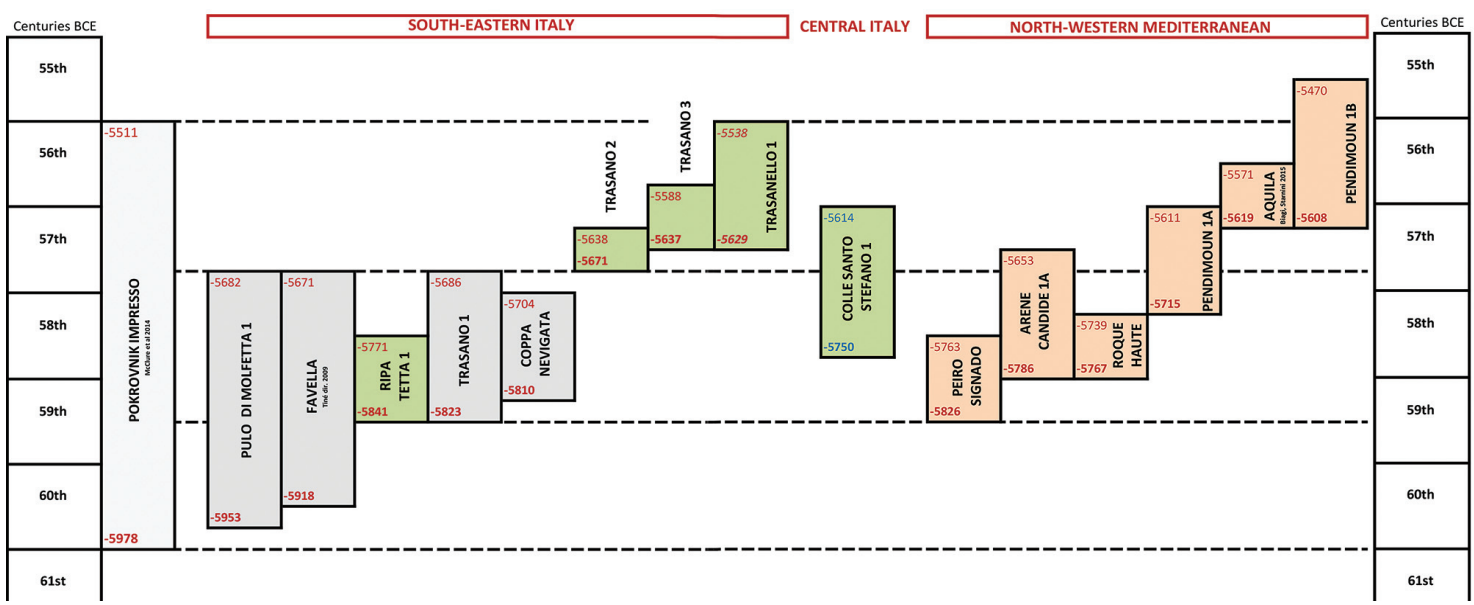

Fig. 6. Periodisation diagram of the Impressa aspects from the Central and Western Mediterranean.

groups. Indeed, some of the north-western pottery assemblages share more characteristics with the distant Apulian and Calabrian settlements than with their closest neighbours.

To date, the early north-western dispersal has been shown to have occurred from about the $59^{\text {th }}$ century, a period during which diversification is observed within the material cultures in south-eastern Italy, i.e. the early emergence of Guadone. Nevertheless, north-western material cultures do not provide evidence of the evolved Guadone patterns, and they globally remain closer to the archaic patterns. Likewise, the origins of the Arene Candide - Peiro Signado style remains unsolved, even if some connections were highlighted on Corfu (Sidari) and Sicily (Kronio) (Guilaine et al. 2016). New work on pottery technology now demonstrates a disconnection between north-western ICC, with a singular Spiral Patchwork technology, and the evolved assemblages from Ripatetta and Colle Santo Stefano, with a standard pan-European coiling technology (Gomart et al. 2017 in press). This reinforces the hypothesis of cultural drift and questions the origin of both com- munities of practices. In this framework, Sicily still constitutes a priority target.

$$
\text { ACKNOWLEDGEMENTS }
$$

This study was undertaken within the framework of the CIMO Project (ANR-14-CE31-009) with the support of the CEPAM, and the partnership of the PROCOME Project (ANR-13-CULT-0001-01).

New cultural, stratigraphic and radiocarbon data have been provided by L. Angeli, J. Guilaine, I. M. Muntoni, G. Radi and C. Tozzi for the southern sites and by D. Binder, M. Brandaglia, F. Briois, L. Gomart, J. Guilaine, R. Maggi, C. Manen, C. Panelli and S. Rossi for the north-western sites.

Regarding the new dates published here, botanical samples were identified thanks to J. Battentier, $L$. Bouby, A. Carré, C. Delhon, P. Marinval, R. Nisbet and $S$. Thiébault, and zoological samples thanks to $L$. Gourichon, S. Massala and P. Rowley-Conwy.

$D$. Binder ran the Bayesian modelling and wrote the paper with the collaboration of $P$. Lanos, who specified the ChronoModel rules and ran an anteriority probability calculus. All the authors discussed the results and interpretations before submission.

\section{$\therefore$}

\section{References}

Albore Livadie C. 2002. La Starza-Campania. In M.-A. Fugazzola Delpino, A. Pessina, V. Tiné (eds.), Le ceramiche impresse nel Neolitico antico. Italia e Mediterraneo. Collana del Bulletino di Paletnologia Italiana. Roma: 541548.

Ammerman A. J. 2013. Setting our sights on the distant horizon. Eurasian Prehistory 11(1-2): 203-236.

Ammerman A. J., Polglase C. 1997. Analyses and descriptions of the obsidian collections from Arene Candide. In
R. Maggi (ed.), Arene Candide: a functional and environmental assessment of the Holocene sequence (Excavations Bernabò Brea - Cardini 1940-1950). Il Calamo. Roma: 573-592.

Ammerman A. J., Shaffer G. D. and Hartmann N. 1988. A Neolithic Household at Piana di Curinga, Italy. Journal of field archaeology 15(2): 121-140.

Angeli L. 2012. Il Neolitico antico nel Materano: le sequenze stratigrafiche di Trasano e Trasanello Cementi- 
ficio. Studio tecno-tipologico della Ceramica Impressa. PhD dissertation. Università degli studi di Pisa. Pisa.

Arobba D., Panelli C., Caramiello R., Gabriele M. and Maggi R. 2017. Cereal remains, plant impressions and ${ }^{14} \mathrm{C}$ direct dating from the Neolithic pottery of Arene Candide Cave (Finale Ligure, NW Italy). Journal of Archaeological Science Reports 12: 395-404.

Balasse M., Tresset A., Dobney K. M. and Ambrose S. H. 2005. The use of isotope ratios to test for seaweed eating in sheep. Journal of Zoology 266(3): 283-291.

Battentier J., Thiébault S., Binder D., Théry-Parisot I., Carré A. and Delhon C. 2015. L'abri Pendimoun (Castellar, Alpes-Maritimes): évolution du couvert forestier et exploitation du milieu au Néolithique (5800-2000 cal. BCE). Quaternaire 26(4): 279-292.

Berger J.F., Metallinou G. and Guilaine J. 2014. Vers une révision de la transition méso-néolithique sur le site de Sidari (Corfou, Grèce). Nouvelles données géoarchéologiques et radiocarbone, évaluation des processus post-dépositionnels. In C. Manen, T. Perrin and J. Guilaine (eds.), La transition néolithique en Méditerranée. Errance and Archives d'Ecologie Préhistorique. Paris and Toulouse: 213-232.

Bernabò Brea L. 1950. Il Neolitico a ceramica impressa e la sua diffusione nel Mediterraneo. Rivista di Studi Liguri 16: 25-36.

Biagi P., Shennan S. and Spataro M. 2005. Rapid rivers and slow seas? New data for the radiocarbon chronology of the Balkan Peninsula. In L. Nikolova, J. Higgins (eds.), Prehistoric Archaeology and Anthropological Theory and Education. International Institute of Anthropology. Salt Lake City: 41-52.

Biagi P., Starnini E. 2016. La cultura della Ceramica Impressa nella Liguria di Ponente (Italia Settentrionale): distribuzione, cronologia e aspetti culturali. In Del Neolític a l'Edat del Bronze en el Mediterrani occidental. Estudis en homenatge a Bernat Martí Oliver. Servicio de Investigación Prehistórica. Trabajos varios. València: 35-49.

Binder D. 2000. Mesolithic and Neolithic interaction in southern France and northern Italy: new data and current hypotheses. In T. D. Price (ed.), Europe's first farmers. Cambridge University Press. Cambridge: 117-143.

2013. Mésolithique et Néolithique ancien en Italie et dans le sud-est de la France entre 7000 et 5500 BCE cal: questions ouvertes sur les dynamiques culturelles et les procès d'interaction. In T. Perrin, C. Manen, G. Marchand, P. Allard, D. Binder and M. Ilett (eds.), Transitions, ruptures et continuité durant la Préhistoire. Congrès préhistorique de France, Bordeaux. Société Préhistorique Française. Paris: 341-355.
Binder D., Battentier J., Delhon C. and Sénépart I. 2017. In pursuit of a missing transition: the Mesolithic and Neolithic radiocarbon chronology at La Font-aux-Pigeons rockshelter. Antiquity 91(357): 605-620.

Binder D., Brochier J.-E., Duday H., Helmer D., Marinval P., Thiébault S. and Wattez J. 1993. L'abri Pendimoun (Castellar, Alpes-Maritimes): nouvelles données sur le complexe culturel de la Céramique Imprimée méditerranéenne dans son contexte stratigraphique. Gallia Préhistoire 35: $177-251$.

Binder D., Gratuze B. and Vaquer J., 2012. La circulation de l'obsidienne dans le sud de la France au Néolithique. Rubricatum 5: 189-200.

Binder D., Guilaine J. 1999. Rapports du groupe de travail sur la néolithisation: la Méditerranée centrale et occidentale. In J. Evin, C. Oberlin, J.-P. Daugas and J.-F. Salles (eds.), ${ }^{14} \mathrm{C}$ et Archéologie $1{ }^{14} \mathrm{C}$ and Archaeology. Actes du 3ème Congrès International/3rd International Symposium (Lyon, 6-10 avril 1998). Société Préhistorique Française. Paris: 454-459.

Binder D., Hamon C., Bellot-Gurlet L., Beyries S., Pradeau J.-V., Vautier F. and Voldoire 0. 2014. First Sculpted Human Face in the W.-Mediterranean Early Neolithic. Cambridge Archaeological Journal 24: 1-17.

Binder D., Maggi R. 2001. Le Néolithique ancien de l'arc liguro-provençal. Bulletin de la Société Préhistorique Française 98(3): 411-422.

Binder D., Nonza-Micaelli A. 2017. Aspects de l'horizon »Impressa« de l'abri Albertini - E Spilonche (Albertacce, Haute-Corse). In J. Sicurani (ed.), Colloque L'Habitat Préet protohistorique, 28-30 avril 2017, résumé des communications. Association de Recherches Préhistoriques et Protohistoriques Corses. Calvi: 5-6.

Binder D., Sénépart I. 2010. La séquence de l'Impressocardial de l'abri Pendimoun et l'évolution des assemblages céramiques en Provence. In C. Manen, F. Convertini, D. Binder and I. Sénépart (eds.), Premières sociétés paysannes de Méditerranée occidentale. Structure des productions céramiques. Société Préhistorique Française. Paris: 149-167.

Branch N. P., Black S., Maggi R. and Marini A. F. 2014. The Neolithisation of Liguria (NW Italy): An environmental archaeological and paleoenvironmental perspective. $E n$ vironmental Archaeology 19(3): 196-213.

Brandaglia M. 1991. Il neolitico a ceramica impressa dell'Isola del Giglio: la ceramica. Studi per l'Ecologia del Quaternario 13: 43-104. 
2002. Isola Del Giglio. Toscana. In M.-A. Fugazzola Delpino, A. Pessina and V. Tiné (eds.), Le ceramiche impresse nel Neolitico antico. Italia e Mediterraneo. Collana del Bulletino di Paletnologia Italiana. Roma: 407-423.

Briois F., Manen C. 2009. L'habitat néolithique ancien de Peiro Signado à Portiragnes (Hérault). In A. Beeching, I. Sénépart (eds.), De la maison au village. L'habitat néolithique dans le Sud de la France et le Nord-Ouest méditerranéen. Société Préhistorique Française. Paris: 31-38.

Briois F., Manen C. and Gratuze B. 2009. Nouveaux résultats sur l'origine des obsidiennes de Peiro Signado à Portiragnes (Hérault). Bulletin de la Société Préhistorique Française 106(4): 809-811.

Capelli C., Starnini E., Cabella R. and Piazza M. 2006. Archaeometric research on the Early Neolithic pottery production in Liguria (Northern Italy): preliminary data from San Sebastiano di Perti (Savona). ArchéoSciences, Revue d'Archéométrie 30: 89-94.

Cassano S. M., Manfredini A. 1987. Nuovi dati sull'insediamento neolitico di Coppa Nevigata. In Atti della XXVI riunione scientifica. Il Neolitico in Italia. Istituto Italiano di Preistoria e Protostoria. Firenze: 743-752.

Castelletti L., Maspero A. and Tozzi 1994. Il popolamento della Valle del Serchio (Toscana settentrionale) durante il Tardiglaciale würmiano et l'Oloccene antico. In P. Biagi, J. G. Nandris (eds.), Highland Zone Exploitation in Southern Europe. Museo civico di Scienze Naturali. Brescia: 189-204.

Cesari J., Courtaud P., Leandri F., Perrin T. and Manen C. 2014. Le site de Campu Stefanu (Sollacaro, Corse-du-Sud): une occupation du Mésolithique et du Néolithique ancien. In C. Manen, T. Perrin and Guilaine J. (ed.), Transitions in the Mediterranean. When hunters became farmers. Transitions en Méditerranée. Ou comment des chasseurs devinrent collecteurs. Errance and Archives d'Ecologie Préhistorique. Paris and Toulouse: 283-306.

Cipolloni Sampò M., Tozzi C. and Verola M.-L. 1999. Le Néolithique ancien dans le sud-est de la péninsule italienne: caractérisation culturelle, économie, structures d'habitat. In J. Vaquer (ed.), Le Néolithique du nord-ouest méditerranéen. Congrès préhistorique de France, Carcassonne. Société Préhistorique Française. Paris: 13-24.

Coppola D. 2001. Grotta Sant'Angelo (Ostuni, Brindisi), scavi 1984: dalla ceramica graffita al linguaggio simbolico. Atti della Società per la Preistoria e Protostoria della Regione Friuli - Venezia Giulia 12: 67-126.

Costantini L., Stancanelli M. 1994. La preistoria agricola dell'Italia centro-meridionale: il contributo delle indagini archeobotaniche. Origini 18: 149-244.
Dean J. S. 1978. Independent Dating in Archaeological Analysis. Advances in Archaeological Method and Theory 1: 223-255.

Del Lucchese A., Starnini E. 2010. Aggiornamenti sulla cultura della ceramica impressa in Liguria. Nuovi dati dall'assemblaggio della ceramica delle Arene Candide. Archeologia in Liguria, Nuova serie 2(2006-2007): 11-26.

Dini M., Fioravanti S. 2011. L'industria castelnoviana di Lama Lite: studio tecno-tipologico. Preistoria Alpina 45: 229-242.

Fabbri C., Petrinelli Pannocchia C. and Radi G., 2011. Colle Santo Stefano di Ortucchio (AQ). Evoluzione della ceramica e dell'industria litica scheggiata a confronto. In $\mathrm{Il} \mathrm{Fu}$ cino e le aree limitrofe nell'antichità. Archeoclub d'Italia. Avezzano: 119-131.

Ferrari S. 2010. Il Mesolitico recente in Emilia e il complesso culturale castelnoviano: dinamiche insediative e sistemi tecnici litici. Unpublished $\mathrm{PhD}$ dissertation. Università degli studi di Ferrara. Ferrara.

Fiorentino G., Caldara M., De Santis V., D'Oronzo C., Muntoni I. M., Simone 0., Primavera M. and Radina F. 2013. Climate changes and human-environment interactions in the Apulia region of south-eastern Italy during the Neolithic period. The Holocene 23(9): 1297-1316.

Forenbaher S., Kaiser T. and Miracle P. T. 2013. Dating the East Adriatic Neolithic. European Journal of Archaeology 16(4): 589-609.

Franco C. 2011. La fine del Mesolitico in Italia. Identità culturale e distribuzione territoriale degli ultimi cacciatori-raccoglitori. Quaderni della Societa per la preistoria e protostoria della regione Friuli Venezia Giulia, 13: $1-278$.

Fugazzola Delpino M.-A., Pessina A. 1999. Le village submergé de La Marmotta (Lac de Bracciano, Rome) In J. Vaquer (ed.), Le Néolithique du nord-ouest méditerranéen. Congrès préhistorique de France, Carcassonne. Société Préhistorique Française. Paris: 35-38.

Gomart, L., Weiner A., Gabriele M., Durrenmath G., Sorin S., Angeli L., Colombo M., Fabbri C., Maggi R., Panelli C., Pisani D., Radi G., Tozzi C. and Binder D. in press. Spiraled patchwork technology: a newly identified pottery-manufacturing sequence sheds light on farming introduction processes into Southern Europe. Antiquity.

Gorgoglione M., Di Lernia S. and Fiorentino G. (eds.) 1995. L'insediamento preistorico di Terragne (Manduria, Taranto). Nuovi dati sul processi di neolitizzazione nel sud-est italiano. Regione Puglia. Manduria. 
Grifoni Cremonesi R., Radi G. 1999. Le Néolithique de l'Italie centrale adriatique. In J. Vaquer (ed.), Le Néolithique du nord-ouest méditerranéen. Congrès préhistorique de France, Carcassonne. Société Préhistorique Française. Paris: $39-50$.

Guilaine J. 2003. De la vague à la tombe. La conquête néolithique de la Méditerranée (8000-2000 avant J.-C.). Le Seuil. Paris.

Guilaine J., Cremonesi G. 1987. L'habitat néolithique de Trasano (Matera, Basilicate): premiers résultats. In Atti della XXVI riunione scientifica. Il neolitico in Italia. Istituto Italiano di Preistoria e Protostoria. Firenze: 707-720.

Guilaine J., Manen C. and Vigne J.-D. (eds.) 2007. Pont de Roque-Haute. Nouveaux regards sur la Néolithisation de la France méditerranéenne. Archives d'Ecologie Préhistorique. Toulouse.

Guilaine J., Metallinou G. and Berger J.-F. 2016. La néolithisation de la Méditerranée occidentale: sur la piste des pionniers? In Del Neolitic a l'Edat del Bronze en el Mediterrani occidental. Estudis en homenatge a Bernat Martí Oliver. Servicio de Investigación Prehistórica. Trabajos varios. València: $27-34$.

Hofmanová Z. and 38 co-authors. 2016. Early farmers from across Europe directly descended from Neolithic Aegeans. Proceedings of the National Academy of Sciences of the USA 113(25): 6886-6891.

Isern N., Zilhão J., Fort J. and Ammerman A. J. 2017. Modelling the role of voyaging in the coastal spread of the Early Neolithic in the West Mediterranean. Proceedings of the National Academy of Sciences of the USA 114(5): 897-902.

Langella M., Boscaino M., Coubray S., Curci A., De Francesco A. M. and Senatore M. R. 2003. Baselice (Benevento): il sito pluristratificato di Torrente Cervaro. Rivista di Scienze Preistoriche 53: 259-336.

Lanos P., Philippe A. 2015a. Hierarchical Bayesian modelling for combining dates in archaeological context. On-line: https://hal.archives-ouvertes.fr/hal-01162404v3

2015b. Event model: a robust Bayesian tool for chronological modelling. On-line: https://hal.archives-ouver tes.fr/hal-01241720

Lanos P., Philippe A., Lanos H. and Dufresne P. 2015. Chronomodel: Chronological Modelling of Archaeological Data using Bayesian Statistics (Version 1.5). On-line: http://www.chronomodel.fr.

Le Bras-Goude G., Binder D., Formicola V., Duday H., Couture-Veschambre C., Hublin J.-J. and Richards M. P. 2006.
Stratégies de subsistance et analyse culturelle de populations néolithiques de Ligurie: approche par l'étude isotopique $\left({ }^{13} \mathrm{C}\right.$ et $\left.{ }^{15} \mathrm{~N}\right)$ des restes osseux. Bulletins et Mémoires de la Société d'Anthropologie de Paris 18(1-2): 4555.

Lugliè C. 2014. The Su Carroppu rock shelter within the process of neolithisation of Sardinia. In C. Manen, T. Perrin, J. Guilaine (eds.), Transitions in the Mediterranean. When hunters became farmers. Transitions en Méditerranée. Ou comment des chasseurs devinrent collecteurs. Errance and Archives d'Ecologie Préhistorique. Paris and Toulouse: 307-326.

Maggi R. (ed.) 1997a. Arene Candide: a functional and environmental assessment of the Holocene sequence (Excavations Bernabò Brea - Cardini 1940-1950). Il Calamo. Roma.

1997b. The radiocarbon chronology. In R. Maggi (ed.), Arene Candide: a functional and environmental assessment of the Holocene sequence (Excavations Bernabò Brea - Cardini 1940-1950). Il Calamo. Roma: 31-52.

Manen C. 2014. Dynamiques spatio-temporelles et culturelles de la néolithisation ouest-méditerranéenne. In $\mathrm{C}$. Manen, T. Perrin and Guilaine J. (ed.), Transitions in the Mediterranean. When hunters became farmers. Transitions en Méditerranée. Ou comment des chasseurs devinrent collecteurs. Errance and Archives d'Ecologie Préhistorique. Paris and Toulouse: 405-418.

Marchand G., Perrin T. 2017. Why this revolution? Explaining the major technical shift in Southwestern Europe during the $7^{\text {th }}$ millennium cal. BC. Quaternary international 428(B): 73-85.

McClure S. B., Podrug E., Moore A. M. T., Culleton B. J. and Kennett D. J. 2014. AMS ${ }^{14} \mathrm{C}$ Chronology and ceramic sequences of early farmers in the Eastern Adriatic. Radiocarbon 56(3): 1019-1038.

Muntoni I. M. 2003. Modellare l'argilla. Vasai del Neolitico antico e medio nelle Murge pugliesi. Instituto Italiano di Preistoria e Protostoria. Firenze.

2009. Early Neolithic ceramics in southern Italy: relationships between pottery technology and production organization In D. Gheorghiu (ed.), Early Farmers, Late Foragers, and Ceramic Traditions. On the Beginning of Pottery in the Near East and Europe. Cambridge Scholar Publishing. Cambridge: 87-115.

2012. Circulation of raw materials, final products or ideas in the Neolithic communities of Southern Italy: the contribution of archeometric analyses to the study of the pottery, flint and obsidian. Rubricatum 5: 403-412. 
Pearce M. 2013. Rethinking the North Italian Early Neolithic. Accordia Research Institute, University of London. London.

Perrin T., Binder D. 2014. Le Mésolithique à trapèzes et la néolithisation de l'Europe sud-occidentale. In C. Manen, T. Perrin and J. Guilaine (eds.), Transitions in the Mediterranean. When hunters became farmers. Transitions en Méditerranée. Ou comment des chasseurs devinrent collecteurs. Errance and Archives d'Ecologie Préhistorique. Paris and Toulouse: 271-282.

Pessina A., Radi G. 2006. La diffusione dell'ossidiana nell'Italia centro-settentrionale. In Atti della XXXIX riunione scientifica. Materie prime e scambi nella Preistoria italiana. Istituto Italiano di Preistoria e Protostoria. Firenze: 435-460.

Produg, E., McClure S. B., Moore A. M. T., Culleton B. J. and Kennett D. J. 2014. New AMS ${ }^{14} \mathrm{C}$ dates for the Neolithic of Northern Dalmatia (Croatia). In XLIX riunione scientifica. Preistoria e Protostoria del Caput Adriae. Istituto Italiano di Preistoria e Protostoria. Firenze. On-line.

Radi, G., Guilaine J., Cremonesi G. and Coularou J. 2000. Trasano e la ceramica impressa del Materano. In A. Pessina, G. Muscio (eds.), La neolitizzazione tra Oriente e Occidente. Edizione del Museo Friulano di Storia Naturale. Udine: 439-450.

Radi G., Boschian G., Calani L., Pistoia A. and Zamagni B. 2001. Nuovi dati dal villagio a ceramica impressa di Colle Santo Stefano (Ortucchio). In Il Fucino e le aree limitrofe nell'antichità. Atti del II convegno di Archeologia in ricordo di Antonio Mario Radmilli e Giuliano Cremonesi. Museo di Preistoria, Celano - Paludi, novembre 1999. Archeoclub d'Italia. Avezzano: 70-81.

Reimer P. J. And 29 co-authors. 2013. IntCal13 and Marine13 radiocarbon age calibration curves $0-50,000$ years cal BP. Radiocarbon 55(4): 1869-1887.

Radina F. 2005. Pulo di Molfetta. Rivista di Scienze Preistoriche LV(Notizario): 537-538.

Roudil J.-L., Soulier M. 1981. Le gisement néolithique ancien de Peiro Signado (Portiragnes, Hérault). Etude préliminaire. In Congrès préhistorique de France, Cahors. Société Préhistorique Française. Paris: 258-279.

Scarcella S. 2011. Les productions céramiques des faciès de Stentinello et Ghar Dalam. Savoirs techniques et interactions culturelles en Méditerranée centrale au Néolithique ancien. PhD dissertation. Ecole des Hautes Etudes en Sciences Sociales. Toulouse.
Skeates R. 1994. A radiocarbon date-list for prehistoric Italy (c. 46,400 BP - 2450/400 cal BC). In R. Skeates, R. D. Whitehouse (eds.), Radiocarbon dating and Italian Prehistory. Accordia Research Institute. University of London. London: 147-288.

Sordinas A. 1967. Radiocarbon dates from Corfu, Greece. Antiquity 41: 64.

Starnini E., Vicino G. 1993. Segnalazione di un sito neolitico in località S. Sebastiano di Perti (Finale Ligure - SV). Rassegna di Archeologia 11: 37-43.

Tiné S. 1987. La néolithisation des pays adriatiques. In J. Guilaine, J. Courtin, J.-L. Roudil and J. L. Vernet (eds.), Premières communautés paysannes en Méditerranée occidentale. Centre national de la recherche scientifique. Paris: 351-355.

Tiné V. (ed.) 2009. Favella. Un villagio neolitico nella Sibaritide. Museo nazionale preistorico etnografico "L. Pigorini". Roma.

Tozzi C. 2002. Ripa Tetta, Puglia. In M.-A. Fugazzola Delpino, A. Pessina and V. Tiné (eds.), Le ceramiche impresse nel Neolitico antico. Italia e Mediterraneo. Collana del Bulletino di Paletnologia Italiana. Roma: 579-588.

Tozzi C., Verola M.-L. 1991. La campagna di scavo 1990 a Ripa Tetta (Lucera, FG). In Atti $12^{\circ}$ Convegno Nazionale sulla Preistoria, Protostoria, Storia della Daunia, San Severo, 1990. Archeoclub d'Italia. Avezzano: 37-48.

Tozzi C., Weiss M.-C. 2001. Nouvelles données sur le Néolithique ancien de l'aire corso-toscane. Bulletin de la Société Préhistorique Française 98(3): 445-458.

Tykot R. H., Freund K. P. and Vianello A. 2013. Source analysis of prehistoric obsidian artifacts in Sicily (Italy) using pXRF. Archaeological Chemistry 8: 195-210.

Vartanian E., Guibert P., Ney C., Bechtel F., Schvoerer M., Guilaine J. and Cremonesi G. 2000. Chronologie de la néolithisation en Italie du sud-est. Nouvelles datations grâce à la thermoluminescence (TL) sur le site de Matera - Trasano. In P. Biagi (ed.), Studi sul Paleolitico, Mesolitico e Neolitico del Bacino dell'Adriatico in ricordo di Antonio M. Radmili. Edizioni Svevo. Trieste: 245-268.

Zilhão J. 2001. Radiocarbon evidence for maritime pioneer colonization at the origins of farming in west Mediterranean Europe. Proceedings of the National Academy of Sciences of the USA 98(24): 14180-14185. 


\section{Appendix}

Tab. 1. Conventional radiocarbon dates and samples of Central and Western Mediterranean ICC considered in this article.

\begin{tabular}{|c|c|c|c|c|c|c|}
\hline Region (district) & & Site & 14C_lab_label & Mean & StE & Sample \\
\hline Ionian islands (Corfu) & Corfu & Sidari & $\begin{array}{l}\text { Ly-5633 } \\
\text { (SacA-13393) }\end{array}$ & 7170 & 40 & Cerealia charred seeds \\
\hline Ionian islands (Corfu) & Corfu & Sidari & $\begin{array}{l}\text { Ly-3172 } \\
\text { (SacA-4513) }\end{array}$ & 7370 & 80 & Quercus sp. charcoal \\
\hline Apulia (Bari) & Molfetta & Pulo di Molfetta & LTL-141A & 6651 & 50 & $\begin{array}{l}\text { Ovis vel Capra, } \\
\text { bone collagen }\end{array}$ \\
\hline Apulia (Bari) & Molfetta & Pulo di Molfetta & LTL-3810A & 6764 & 60 & $\begin{array}{l}\text { Ovis vel Capra, } \\
\text { bone collagen }\end{array}$ \\
\hline Apulia (Bari) & Molfetta & Pulo di Molfetta & LTL-4536A & 6983 & 50 & $\begin{array}{l}\text { Ovis vel Capra, } \\
\text { bone collagen }\end{array}$ \\
\hline Apulia (Bari) & Molfetta & Pulo di Molfetta & LTL-142A & 7134 & 60 & $\begin{array}{l}\text { Ovis vel Capra, } \\
\text { bone collagen }\end{array}$ \\
\hline Apulia (Brindisi) & Ostuni & Sant'Angelo & Gif-6722 & 6530 & 70 & Cerealia charred seeds \\
\hline Apulia (Brindisi) & Ostuni & Sant'Angelo & Gif-6724 & 6980 & 70 & Triticum sp. charred seeds \\
\hline Apulia (Foggia) & Lucera & Rippa Tetta & Beta-47808 & 6890 & 60 & Cerealia charred seeds \\
\hline Apulia (Foggia) & Lucera & Rippa Tetta & LTL-16676A & 6910 & 40 & $\begin{array}{l}\text { Cerealia charred seeds } \\
\text { fragments }\end{array}$ \\
\hline Apulia (Foggia) & Lucera & Rippa Tetta & LTL-16677A & 6988 & 45 & $\begin{array}{l}\text { Cerealia charred seeds } \\
\text { fragments }\end{array}$ \\
\hline Apulia (Foggia) & Manfredonia & Coppa Nevigata & OxA-1474 & 6850 & 80 & Cerealia charred seeds \\
\hline Apulia (Foggia) & Manfredonia & Coppa Nevigata & OxA-1475 & 6880 & 90 & Hordeum sp. charred seeds \\
\hline Apulia (Tarente) & Manduria & Terragne & Beta-59934 & 6930 & 70 & Cervus sp, bone collagen \\
\hline Apulia (Tarente) & Manduria & Terragne & Beta- 67093 & 7260 & 60 & $\begin{array}{l}\text { Bos primigenius bone } \\
\text { collagen }\end{array}$ \\
\hline Basilicate (Matera) & Matera & Trasano & Ly -3951 (OxA) & 6840 & 35 & Cerealia charred seeds \\
\hline Basilicate (Matera) & Matera & Trasano & Ly -3949 (OxA) & 6730 & 40 & Cerealia charred seeds \\
\hline Basilicate (Matera) & Matera & Trasano & Ly $-3950(O x A)$ & 6810 & 35 & Cerealia charred seeds \\
\hline Basilicate (Matera) & Matera & Trasano & Ly $-3948(O x A)$ & 6710 & 35 & Cerealia charred seeds \\
\hline Basilicate (Matera) & Matera & Trasano & Ly -3952 (OxA) & 6760 & 40 & Cerealia charred seeds \\
\hline Basilicate (Matera) & Matera & Trasano & Ly -3953 (OxA) & 6730 & 40 & Cerealia charred seeds \\
\hline Basilicate (Matera) & Matera & Trasano & Ly $-3954(O x A)$ & 6835 & 40 & Cerealia charred seeds \\
\hline Basilicate (Matera) & Matera & Trasano & Ly $-3955(O x A)$ & 6935 & 40 & Cerealia charred seeds \\
\hline Basilicate (Matera) & Matera & Trasanello & LTL-12139A & 6301 & 45 & Unspecified charcoal \\
\hline Basilicate (Matera) & Matera & Trasanello & LTL-12146A & 6614 & 45 & Unspecified charcoal \\
\hline Basilicate (Matera) & Matera & Trasanello & LTL-12142A & 6644 & 45 & Unspecified charcoal \\
\hline Basilicate (Matera) & Matera & Trasanello & LTL-12143A & 6683 & 45 & Unspecified charcoal \\
\hline Basilicate (Matera) & Matera & Trasanello & LTL-12144A & 6632 & 45 & Unspecified charcoal \\
\hline Basilicate (Matera) & Matera & Trasanello & LTL-12145A & 6612 & 45 & Unspecified charcoal \\
\hline Calabria (Cosenza) & Corigliano Calabro & Favella della Corte & Beta- 165482 & 6940 & 40 & Cerealia charred seeds \\
\hline Calabria (Cosenza) & Corigliano Calabro & Favella della Corte & Beta-71633 & 6910 & 60 & Cerealia charred seeds \\
\hline Calabria (Cosenza) & Corigliano Calabro & Favella della Corte & LTL-2O2A & 6956 & 75 & Cerealia charred seeds \\
\hline Calabria (Cosenza) & Corigliano Calabro & Favella della Corte & LTL-203A & 6890 & 50 & Cerealia charred seeds \\
\hline Calabria (Cosenza) & Corigliano Calabro & Favella della Corte & LTL-204A & 6793 & 40 & Bone collagen \\
\hline Calabria (Cosenza) & Corigliano Calabro & Favella della Corte & LTL-778A & 7003 & 55 & Bone collagen \\
\hline Abruzzi (L'Aquila) & Ortucchio & Colle Santo Stefano & LTL-15952A & 6809 & 45 & $\begin{array}{l}\text { Triticum dicoccum } \\
\text { charred seed }\end{array}$ \\
\hline Abruzzi (L'Aquila) & Ortucchio & Colle Santo Stefano & LTL-15953A & 6770 & 45 & $\begin{array}{l}\text { Triticum cf. dicoccum } \\
\text { charred seed }\end{array}$ \\
\hline Tuscany (Grossetto) & Isola del Giglio & Le Secche & LTL-16671A & 6637 & 45 & Erica sp. charcoal \\
\hline Tuscany (Grossetto) & Isola del Giglio & Le Secche & LTL-16672A & 6769 & 45 & Erica sp. charcoal \\
\hline Tuscany (Grossetto) & Isola del Giglio & Le Secche & LTL-16673A & 6492 & 65 & Erica sp. charcoal \\
\hline
\end{tabular}




\begin{tabular}{|c|c|c|c|}
\hline Identification & Field_label & Cultural attibution & Referneces \\
\hline- & Hearth $5 b-5 c$ & Archaic Impressa & Berger et al. 2014 \\
\hline S. Thiébault & Pit 4 & $\begin{array}{l}\text { End of the Monochrome } \\
\text { phase }\end{array}$ & Berger et al. 2014 \\
\hline S. Massala & Phase II, US49 & Archaic Impressa & Unpublished, I. Muntoni \\
\hline S. Massala & Phase Isup, US46 & Archaic Impressa & Unpublished, I. Muntoni \\
\hline S. Massala & Phase I, US10 & Archaic Impressa & Unpublished, I. Muntoni \\
\hline S. Massala & Phase I, US1O & Archaic Impressa & Fiorentino et al. 2013 \\
\hline L. Costantini & Level 6-7 & Red painted wares & Coppola 2001 \\
\hline L. Costantini & Level 9 & Evolved Impressa (Guadone) & Coppola 2001 \\
\hline L. Costantini & Cobble paved area (C9) & Evolved Impressa (Guadone) & Costantini, Stancanelli 1994 \\
\hline L. Bouby & Cobble paved area, TG1 B (I-M3O), \#B & Evolved Impressa (Guadone) & Unpublished, CIMO project \\
\hline L. Bouby & Cobble paved area, $\mathrm{TG}_{1} \mathrm{~B}\left(\mathrm{I}-\mathrm{M}_{3} \mathrm{O}\right)$, \#A & Evolved Impressa (Guadone) & Unpublished, CIMO project \\
\hline L. Costantini & Phase II-III & Archaic Impressa & Skeates 1994 \\
\hline L. Costantini & Phase II-III & Archaic Impressa & Skeates 1994 \\
\hline C. Corridi & US4-5 & Late Mesolithic? & Gorgoglione et al. 1995 \\
\hline C. Corridi & $\mathrm{US}_{4-5}$ & Late Mesolithic ? & Gorgoglione et al. 1995 \\
\hline P. Marinval & Sector A (T44), C2inf & Archaic Impressa & Unpublished, J. Guilaine \\
\hline P. Marinval & Sector A (U48), C2.0 & Evolved Impressa & Unpublished, J. Guilaine \\
\hline P. Marinval & Sector A (U48), C2C & Archaic Impressa & Unpublished, J. Guilaine \\
\hline P. Marinval & Sector A (U48-49), $C_{1}$ & Recent Impressa & Unpublished, J. Guilaine \\
\hline P. Marinval & Sector B (AB46), C2.1 & Recent Impressa & Unpublished, J. Guilaine \\
\hline P. Marinval & Sector B (AB42), $C_{2.2}$ & Evolved Impressa & Unpublished, J. Guilaine \\
\hline P. Marinval & Sector B (AA44), C2.3 & Archaic Impressa & Unpublished, J. Guilaine \\
\hline P. Marinval & Sector B (AA-AB south), C2.4 & Archaic Impressa & Unpublished, J. Guilaine \\
\hline- & Trench 11, US3sup, internal ditch edge & Red painted wares & Unpublished, L. Angeli \\
\hline- & Trench 11 , US3inf, internal ditch edge (F4) & Red painted wares & Unpublished, L. Angeli \\
\hline- & Trench 11 , US5, sherd concentration & Late Impressa & Unpublished, L. Angeli \\
\hline - & Trench 11, US5 (B3) & Late Impressa & Unpublished, L. Angeli \\
\hline - & Trench 11, US5 (C4) & Late Impressa & Unpublished, L. Angeli \\
\hline - & Trench 11, US5, ditch filing & Late Impressa & Unpublished, L. Angeli \\
\hline S. Coubray & Structure D, Pit Y, US4_XIII & Archaic Impressa & Tiné 2009 \\
\hline S. Coubray & Structure A, Pit Z, US4_VI & Archaic Impressa & Tiné 2009 \\
\hline S. Coubray & Structure $E$, Pit T, US3 & Archaic Impressa & Tiné 2009 \\
\hline S. Coubray & Structure E, Pit 30, US4_II & Archaic Impressa & Tiné 2009 \\
\hline S. Coubray & Structure D, Pit Y, US4_II & Archaic Impressa & Tiné 2009 \\
\hline S. Coubray & Structure G, Pit 10, US3_VI & Archaic Impressa & Tiné 2009 \\
\hline L. Bouby & Cobble paved area $\left(\mathrm{H}_{2} \mathrm{O}\right), \mathrm{US} 17, \# \mathrm{~A}$ & Evolved Impressa (Guadone) & Unpublished, CIMO project \\
\hline L. Bouby & Cobble paved area $\left(\mathrm{H}_{20}\right), \mathrm{US}_{17}, \# \mathrm{~B}$ & Evolved Impressa (Guadone) & Unpublished, CIMO project \\
\hline C. Delhon & Grey sediment \#1 & Impressa / Cardial & Unpublished, CIMO project \\
\hline C. Delhon & Brown sediment \#2 & Impressa / Cardial & Unpublished, CIMO project \\
\hline C. Delhon & Brown sediment \#3 & Impressa / Cardial & Unpublished, CIMO project \\
\hline
\end{tabular}




\begin{tabular}{|c|c|c|c|c|c|c|}
\hline Region (district) & & Site & 14C_lab_label & Mean & StE & Sample \\
\hline Liguria (Savona) & Finale-Ligure & Arene Candide & LTL-15943A & 6834 & 45 & Ovis aries bone collagen \\
\hline Liguria (Savona) & Finale-Ligure & Arene Candide & LTL-15944A & 6864 & 45 & Ovis aries bone collagen \\
\hline Liguria (Savona) & Finale-Ligure & Arene Candide & LTL-15946A & 6750 & 45 & $\begin{array}{l}\text { Vitis vinifera ssp. sylvestris } \\
\text { charred seed }\end{array}$ \\
\hline Liguria (Savona) & Finale-Ligure & Arene Candide & LTL-15947A & 6861 & 45 & Ovis aries bone collagen \\
\hline Liguria (Savona) & Finale-Ligure & Arene Candide & LTL-16680A & 6271 & 40 & Capra hircus bone collagen \\
\hline Liguria (Savona) & Finale-Ligure & Arene Candide & LTL-16681A & 6623 & 45 & Bos taurus bone collagen \\
\hline Liguria (Savona) & Finale-Ligure & Arene Candide & LTL-16678A & 6751 & 45 & Capra hircus bone collagen \\
\hline Liguria (Savona) & Finale-Ligure & Arene Candide & LTL-6004A & 6446 & 45 & $\begin{array}{l}\text { Triticum monococcum } \\
\text { charred spikelet and fork }\end{array}$ \\
\hline Liguria (Savona) & Finale-Ligure & Arene Candide & Beta- 66552 & 6150 & 70 & Phillyrea sp. charcoal \\
\hline Liguria (Savona) & Finale-Ligure & Arene Candide & Beta- 66553 & 6880 & 60 & $\begin{array}{l}\text { Pistachia terebinthus } \\
\text { charcoal }\end{array}$ \\
\hline Liguria (Savona) & Finale-Ligure & Arene Candide & Beta-170557 & 6870 & 40 & $\begin{array}{l}\text { Triticum monococcum } \\
\text { charred seeds }\end{array}$ \\
\hline Liguria (Savona) & Finale-Ligure & Arene Candide & Beta-170558 & 6860 & 40 & Cornus sp. charred seed \\
\hline Liguria (Savona) & Finale-Ligure & Arene Candide & OxA-23072 & 6778 & 39 & $\begin{array}{l}\text { Triticum dicoccum } \\
\text { charred seeds }\end{array}$ \\
\hline Liguria (Savona) & Finale-Ligure & Arene Candide & Beta-110542 & 6830 & 40 & Hordeum sp. charred seeds \\
\hline Liguria (Savona) & Finale-Ligure & Arene Candide & Beta- 170555 & 6700 & 40 & Euphorbia sp. charcoal \\
\hline Liguria (Savona) & Finale-Ligure & Arene Candide & Beta-109619 & 6370 & 50 & Rhamnus alaternus charcoal \\
\hline Liguria (Savona) & Finale-Ligure & San Sebastiano di Perti & GrA-25715 & 6760 & 45 & Hordeum sp. charred seeds \\
\hline Liguria (Savona) & Finale-Ligure & San Sebastiano di Perti & OxA-21359 & 6767 & 39 & $\begin{array}{l}\text { Triticum dicoccum } \\
\text { charred seeds }\end{array}$ \\
\hline Liguria (Savona) & Finale-Ligure & San Sebastiano di Perti & OxA-19734 & 6675 & 33 & Triticum vulgare \\
\hline Liguria (Savona) & Orco Feglino & Arma dell'Aquila & $O x A-V-2365-31$ & 6678 & 33 & Human bone collagen \\
\hline Liguria (Savona) & Orco Feglino & Arma dell'Aquila & OxA-V-2365-50 & 6669 & 34 & Human bone collagen \\
\hline $\begin{array}{l}\text { Provence } \\
\text { (Alpes-Maritimes) }\end{array}$ & Castellar & Pendimoun & GrA-26893 & 6445 & 40 & Human bone collagen \\
\hline $\begin{array}{l}\text { Provence } \\
\text { (Alpes-Maritimes) }\end{array}$ & Castellar & Pendimoun & LTL-15940A & 6399 & 45 & Cerealia charred seeds \\
\hline $\begin{array}{l}\text { Provence } \\
\text { (Alpes-Maritimes) }\end{array}$ & Castellar & Pendimoun & LTL-15941A & 6803 & 45 & Arbutus unedo charcoal \\
\hline $\begin{array}{l}\text { Provence } \\
\text { (Alpes-Maritimes) }\end{array}$ & Castellar & Pendimoun & GrA-29528 & 6650 & 45 & Cerealia charred seeds \\
\hline $\begin{array}{l}\text { Provence } \\
\text { (Alpes-Maritimes) }\end{array}$ & Castellar & Pendimoun & GrA-29403 & 6725 & 45 & Cerealia charred seeds \\
\hline $\begin{array}{l}\text { Provence } \\
\text { (Alpes-Maritimes) }\end{array}$ & Castellar & Pendimoun & LTL-15942A & 6745 & 45 & Maloideae charcoal \\
\hline $\begin{array}{l}\text { Provence } \\
\text { (Alpes-Maritimes) }\end{array}$ & Castellar & Pendimoun & $\begin{array}{l}\text { Lyon-1713 } \\
\text { (GrA-20195) }\end{array}$ & 6790 & 50 & Pomoideae charcoal \\
\hline $\begin{array}{l}\text { Provence } \\
\text { (Alpes-Maritimes) }\end{array}$ & Castellar & Pendimoun & LTL-8012A & 6499 & 45 & $\begin{array}{l}\text { Quercus sp. } \\
\text { charred seeds }\end{array}$ \\
\hline $\begin{array}{l}\text { Provence } \\
\text { (Alpes-Maritimes) }\end{array}$ & Castellar & Pendimoun & LTL-8011A & 6507 & 45 & $\begin{array}{l}\text { Quercus sp. } \\
\text { charred seeds }\end{array}$ \\
\hline $\begin{array}{l}\text { Provence } \\
\text { (Alpes-Maritimes) }\end{array}$ & Castellar & Pendimoun & LTL-14104A & 6466 & 40 & $\begin{array}{l}\text { Corylus avellana } \\
\text { charcoal }\end{array}$ \\
\hline $\begin{array}{l}\text { Provence } \\
\text { (Alpes-Maritimes) }\end{array}$ & Castellar & Pendimoun & LTL-8007A & 6170 & 45 & $\begin{array}{l}\text { Quercus sp. } \\
\text { charred seeds }\end{array}$ \\
\hline $\begin{array}{l}\text { Provence } \\
\text { (Alpes-Maritimes) }\end{array}$ & Castellar & Pendimoun & LTL-8008A & 6337 & 45 & $\begin{array}{l}\text { Quercus sp. } \\
\text { charred seeds }\end{array}$ \\
\hline $\begin{array}{l}\text { Provence } \\
\text { (Alpes-Maritimes) }\end{array}$ & Castellar & Pendimoun & LTL-8009A & 6241 & 45 & $\begin{array}{l}\text { Corylus avellana } \\
\text { charred fruit }\end{array}$ \\
\hline $\begin{array}{l}\text { Provence } \\
\text { (Alpes-Maritimes) }\end{array}$ & Castellar & Pendimoun & LTL-8010A & 6328 & 45 & $\begin{array}{l}\text { Quercus sp. } \\
\text { charred seeds }\end{array}$ \\
\hline $\begin{array}{l}\text { Provence } \\
\text { (Alpes-Maritimes) }\end{array}$ & Castellar & Pendimoun & GrA-32061 & 6450 & 40 & Human bone collagen \\
\hline
\end{tabular}




\begin{tabular}{|c|c|c|c|}
\hline Identification & Field_label & Cultural attibution & Referneces \\
\hline P. Rowley-Conwy & Phase $A C_{1}$, US 347 & Impressa & Unpublished, CIMO project \\
\hline P. Rowley-Conwy & Phase $A C_{1}, U_{3} 60$ & Impressa & Unpublished, CIMO project \\
\hline R. Nisbet & Phase $A C_{1}, \cup S_{351} A$ & Impressa & Unpublished, CIMO project \\
\hline P. Rowley-Conwy & Phase AC2, US330 (anatomical connection) & Impressa & Unpublished, CIMO project \\
\hline P. Rowley-Conwy & Phase $\mathrm{AC}_{3}, \mathrm{US} 312, \mathrm{AA}$ & Cardial & Unpublished, CIMO project \\
\hline P. Rowley-Conwy & Phase $A C_{3}, \cup S_{312}, \# B$ & Cardial & Unpublished, CIMO project \\
\hline P. Rowley-Conwy & Phase $\mathrm{AC}_{3}, \mathrm{US}_{306}, \mathrm{~B}$ & Cardial & Unpublished, CIMO project \\
\hline D. Arobba & Cf. Phase $\mathrm{AC}_{3}$, US26, \#Cardial pot & Cardial & Arobba et al. 2017 \\
\hline R. Nisbet & Cf. Phase $\mathrm{AC}_{4} /$, US27C & Impressa / Cardial & Maggi $1997 b$ \\
\hline R. Nisbet & Cf. Phase $\mathrm{AC}_{1} /, \mathrm{US}_{27} \mathrm{G}$ & Impressa / Cardial & Maggi $1997 b$ \\
\hline R. Nisbet & Phase $A C_{1}, U_{10} A$ & Impressa & Unpublished, R. Maggi \\
\hline R. Nisbet & Phase $A C_{1}, U S_{10} A$ & Impressa & Unpublished, R. Maggi \\
\hline R. Nisbet & Phase $A C_{1}$, USio & Impressa & Biagi, Starnini 2016 \\
\hline R. Nisbet & Phase $A C_{1}$, US 10 & Impressa & Unpublished, R. Maggi \\
\hline R. Nisbet & Phase $A C_{2}$, USgBbase & Impressa & Unpublished, R. Maggi \\
\hline R. Nisbet & Phase $A C_{3}, U S_{9} B$ & Cardial & Unpublished, R. Maggi \\
\hline D. Arobba & Unique layer & Impressa & Biagi, Starnini 2016 \\
\hline D. Arobba & Unique layer & Impressa & Biagi, Starnini 2016 \\
\hline D. Arobba & Unique layer & Impressa & Biagi, Starnini 2016 \\
\hline- & Child burial & Impressa & Biagi, Starnini 2016 \\
\hline- & Layer 7 & Impressa & Biagi, Starnini 2016 \\
\hline H. Duday, G. Goude & Sector South, Burial F1, \#N16_6o6 & Cardial & Binder, Sénépart 2010 \\
\hline L. Bouby, A. Carré & Sector South, US28781-sup, \#28898 & Cardial & Unpublished, CIMO project \\
\hline J. Battentier & Sector South, Pit, US28781-inf, \#28905 & Impressa & Unpublished, CIMO project \\
\hline L. Bouby, A. Carré & Sector South, Pit, US28889, \#28941 & Impressa & Binder, Sénépart 2010 \\
\hline L. Bouby, A. Carré & Sector South, US28889, \#28938 & Impressa & Binder, Sénépart 2010 \\
\hline J. Battentier & Sector South, Pit, US29203, \#29223 & Impressa & Unpublished, CIMO project \\
\hline S. Thiébault & Sector South, US5711, \#5720 & Impressa & Unpublished, D. Binder \\
\hline L. Bouby, A. Carré & Sector North, US18364, \#18512 & Cardial & Unpublished, D. Binder \\
\hline L. Bouby, A. Carré & Sector North, US18364, \#18365 & Cardial & Unpublished, D. Binder \\
\hline J. Battentier & Sector North, US19000, \#41859 & Cardial & Unpublished, D. Binder \\
\hline L. Bouby, A. Carré & Sector North, US19001, \#44387 & Cardial & Unpublished, D. Binder \\
\hline L. Bouby, A. Carré & Sector North, US19001, \#44473 & Cardial & Unpublished, D. Binder \\
\hline L. Bouby, A. Carré & Sector North, US42370, \#42861 & Cardial & Unpublished, D. Binder \\
\hline L. Bouby, A. Carré & Sector North, US42370, \#44077 & Cardial & Unpublished, D. Binder \\
\hline H. Duday, G. Goude & Sector North, Burial H2, US43000, \#43220 & Cardial & Binder, Sénépart 2010 \\
\hline
\end{tabular}


D. Binder, P. Lanos, L. Angeli, L. Gomart, J. Guilaine, C. Manen, R. Maggi, I. M. Muntoni, C. Panelli, G. Radi, C. Tozzi, D. Arobba ...

\begin{tabular}{|c|c|c|c|c|c|c|}
\hline Region (district) & & Site & 14C_lab_label & Mean & StE & Sample \\
\hline $\begin{array}{l}\text { Provence } \\
\text { (Alpes-Maritimes) }\end{array}$ & Castellar & Pendimoun & GrA-26894 & 6440 & 40 & Human bone collagen \\
\hline $\begin{array}{l}\text { Provence } \\
\text { (Alpes-Maritimes) }\end{array}$ & Castellar & Pendimoun & LTL-13788A & 6547 & 45 & Bryonia sp. charred seeds \\
\hline $\begin{array}{l}\text { Provence } \\
\text { (Alpes-Maritimes) }\end{array}$ & Castellar & Pendimoun & LTL-13787A & 6666 & 45 & Bryonia sp. charred seeds \\
\hline $\begin{array}{l}\text { Provence } \\
\text { (Alpes-Maritimes) }\end{array}$ & Castellar & Pendimoun & LTL-8005A & 6599 & 45 & Triticum dicoccum charred seeds \\
\hline $\begin{array}{l}\text { Provence } \\
\text { (Alpes-Maritimes) }\end{array}$ & Castellar & Pendimoun & LTL-8006A & 6649 & 45 & Triticum dicoccum charred seeds \\
\hline $\begin{array}{l}\text { Provence } \\
\text { (Alpes-Maritimes) }\end{array}$ & Castellar & Pendimoun & LTL-8003A & 6452 & 45 & Quercus sp. charred seeds \\
\hline $\begin{array}{l}\text { Provence } \\
\text { (Alpes-Maritimes) }\end{array}$ & Castellar & Pendimoun & LTL-8004A & 6507 & 45 & Quercus sp. charred seeds \\
\hline $\begin{array}{l}\text { Provence } \\
\text { (Alpes-Maritimes) }\end{array}$ & Castellar & Pendimoun & LTL-8002A & 6539 & 45 & Quercus sp. charred seeds \\
\hline $\begin{array}{l}\text { Provence } \\
\text { (Alpes-Maritimes) }\end{array}$ & Castellar & Pendimoun & LTL-8001A & 6600 & 45 & Triticum sp. charred seeds \\
\hline $\begin{array}{l}\text { Provence } \\
\text { (Alpes-Maritimes) }\end{array}$ & Castellar & Pendimoun & GrA-26897 & 6500 & 40 & Quercus sp. charred seeds \\
\hline $\begin{array}{l}\text { Provence } \\
\text { (Alpes-Maritimes) }\end{array}$ & Castellar & Pendimoun & GrA-26895 & 6605 & 40 & Quercus sp. charred seeds \\
\hline Occitanie (Hérault) & Portiragnes & Peiro-Signado & Ly-5688 & 6910 & 40 & Cerealia charred seeds \\
\hline Occitanie (Hérault) & Portiragnes & Peiro-Signado & Ly-5689 & 6925 & 45 & Cerealia charred seeds \\
\hline Occitanie (Hérault) & Portiragnes & Pont de Roque-Haute & Beta-398950 & 6920 & 30 & Triticum dicoccum charred seeds \\
\hline Occitanie (Hérault) & Portiragnes & Pont de Roque-Haute & Beta-398951 & 6870 & 30 & Triticum dicoccum charred seeds \\
\hline Occitanie (Hérault) & Portiragnes & Pont de Roque-Haute & $\begin{array}{l}\text { Ly-9879 } \\
\text { (SacA-32046) }\end{array}$ & 7010 & 60 & Triticum dicoccum charred seeds \\
\hline Occitanie (Hérault) & Portiragnes & Pont de Roque-Haute & Beta-398952 & 6910 & 30 & Triticum dicoccum charred seeds \\
\hline Occitanie (Hérault) & Portiragnes & Pont de Roque-Haute & $\begin{array}{l}\text { Ly-9878 } \\
(\mathrm{SaA}-32045)\end{array}$ & 6820 & 35 & Triticum dicoccum charred seeds \\
\hline
\end{tabular}




\begin{tabular}{|c|c|c|c|}
\hline Identification & Field_label & Cultural attibution & Referneces \\
\hline H. Duday, G. Goude & Sector North, Burial F2, \#K16_6o3 & Cardial & Binder, Sénépart 2010 \\
\hline L. Bouby, A. Carré & Sector North, US47799-sup, \#48256 & Cardial & Unpublished, D. Binder \\
\hline L. Bouby, A. Carré & Sector North, US47799-inf, \#47889 & Impressa & Unpublished, D. Binder \\
\hline L. Bouby, A. Carré & Sector North, US41678, \#47328 & Impressa & Binder et al. 2014 \\
\hline L. Bouby, A. Carré & Sector North, US41678, \#47292 & Impressa & Binder et al. 2014 \\
\hline L. Bouby, A. Carré & Sector North, US47800, \#47783 & Impressa & Unpublished, D. Binder \\
\hline L. Bouby, A. Carré & Sector North, US47800, \#47915 & Impressa & Unpublished, D. Binder \\
\hline L. Bouby, A. Carré & Sector North, US47801, \#48150 & Impressa & Unpublished, D. Binder \\
\hline L. Bouby, A. Carré & Sector North, US47801, \#48041 & Impressa & Unpublished, D. Binder \\
\hline L. Bouby, A. Carré & Sector North, US2067, \#2070 & Impressa & Binder, Sénépart 2010 \\
\hline L. Bouby, A. Carré & Sector North, US2067, \#2066 & Impressa & Binder, Sénépart 2010 \\
\hline P. Marinval & Unique layer & Impressa & Unpublished, F. Briois \\
\hline P. Marinval & Unique layer & Impressa & Unpublished, F. Briois \\
\hline L. Bouby & Pit F1_base & Impressa & Unpublished, PROCOME project \\
\hline L. Bouby & Pit F1_base & Impressa & Unpublished, PROCOME project \\
\hline L. Bouby & Pit $F_{1}$ & Impressa & Unpublished, L. Bouby \\
\hline L. Bouby & Pit F1 & Impressa & Unpublished, L. Bouby \\
\hline L. Bouby & Pit $\mathrm{F}_{1}$ & Impressa & Guilaine et al. 2007 \\
\hline
\end{tabular}

\section{back to contents}

